\title{
HMRC'S MANAGEMENT OF THE UK TAX SYSTEM: THE BOUNDARIES OF LEGITIMATE DISCRETION
}

\author{
Judith Freedman \\ John Vella
}

OXFORD UNIVERSITY CENTRE FOR BUSINESS TAXATION SAÏD BUSINESS SCHOOL, PARK END STREET OXFORD OX1 1HP 


\title{
HMRC'S MANAGEMENT OF THE UK TAX SYSTEM: THE BOUNDARIES OF LEGITIMATE DISCRETION
}

\author{
Draft $8^{\text {th }}$ October \\ Judith Freedman and John Vella*
}

\section{INTRODUCTION}

Taxation provides a critical point of contact between the individual and the state. It requires a number of delicate balances to be negotiated, ensuring, on the one hand, that the tax imposed by the legislature is collected in an effective and efficient manner and, on the other, that taxpayers' rights and interests are respected.

Whilst it is generally accepted that revenue authorities need to be able to employ some discretion in the exercise of their duties, much difficulty is encountered in agreeing on the breadth of discretion to be allowed. Indeed, the benefits of discretion, (including the smooth and efficient operation of the tax system, allowances for minor corrections and robust defences against attempts at manipulation by taxpayers) find a counterweight in strong demands from taxpayers for certainty, legitimacy, consistency and equality. The property and business interests involved in taxation lead some to suggest that certainty in tax law is of the utmost importance- perhaps even more so than in other areas of law. This view stems from a deep-seated notion, arising from a history of hard fought political battles, that taxation of property and labour is a form of legitimated property confiscation requiring powerful justification. ${ }^{1}$ Even those who argue the contrary view, that all taxpayers can ever be entitled to is what they are left with after taxation, ${ }^{2}$ would presumably agree that that taxation must be legitimately levied, according to the tests of legitimacy applicable in the relevant state.

Taxpayer protection is guaranteed ultimately by the constitutional principles which underpin each national tax system. Debates on the amount of discretion that can be and ought to be vested in revenue authorities must thus take place against the background of each country's specific constitutional principles. These principles will define the outer boundary of the discretion that may be allowed under that particular legal system. In the UK, in a revenue law context, these principles include the supremacy of Parliament and the rule of law, Article 4 of the Bill of Rights Act 1689 which vests the sole authority to tax in Parliament, the Treaties of the European Union and principles deriving from them, to the extent that they are relevant in any given

\footnotetext{
*Professor of Taxation Law, University of Oxford and Director of Legal Research, Oxford Centre for Business Taxation and Senior Research Fellow, Oxford Centre for Business Taxation respectively.

${ }^{1}$ H. H. Monroe, Intolerable Inquisition Reflections on the Law of Tax (Stevens \&Sons, 1981); R. Nozick, Anarchy, State and Utopia, (Blackwell Publishing,1974) at p. 169.

${ }^{2}$ L. Murphy and T. Nagel, The Myth of Ownership, (OUP, 2002) at p. 9.
} 
case; the principles emerging out of the Human Rights Act 1998 and, potentially, the HMRC Charter. ${ }^{3}$

HMRC's discretion may be controlled by the courts in substantive cases which apply and interpret legislation and previous judicial decisions which have built up binding case law , through cases brought under the Human Rights Act 1998, which empowers the courts to strike down any exercise of power by a public authority that infringes the European Convention for the Protection of Human Rights and Fundamental Freedoms (the European Convention) ${ }^{4}$ and through the public law action for judicial review.

In order to evaluate the desirable amount of discretion to be vested in the revenue authority it is necessary to weigh up a number of factors, both competing and complimentary. These include the relevant constitutional principles (as these have been developed over many years to provide essential safeguards), efficiency, equity as between taxpayers, administrative resource constraints, compliance costs of taxpayers, risk of revenue loss and the international competitiveness of the tax system as a whole. This paper investigates the extent of the discretion vested in the UK on its tax authority, Her Majesty's Revenue and Customs (HMRC) in light of the relevant constitutional principles and the boundaries of that discretion

This paper proceeds as follows. In part two it outlines and attempts to classify some different types of discretion employed by HMRC. In part three, the paper discusses in more detail the different constitutional principles governing the position. In part four it discusses the remedies available to the taxpayer in cases where there is a question of whether HMRC has exceeded its legitimate discretion. In part five, the authors analyse some topical and contentious examples of the use of discretion in relation to extra-statutory guidance and its application. Part six concludes that there is indeed a delicate balance between the requirements of operational necessity on the one hand and the legitimacy of the functioning of the tax system on the other. There are valuable protections available to taxpayers through the courts but these are subject to many restrictions, expensive to pursue and can raise difficult procedural issues. At present there is also a lack of clarity around the nature and permissibility of different types of concession and their relationship with extra-statutory guidance, which may be in part interpretation and in part concessionary. If extra-statutory guidance is to play an increasing role in UK tax law, which seems likely especially given the move towards broadly drawn anti-avoidance provisions and principles based legislation, then it is desirable for a more explicit framework to be developed to ensure that an appropriate balance is maintained. A first step might be a strengthening of the HMRC Charter in this regard.

\section{HMRC AND ITS EXERCISE OF DISCRETION}

HMRC exercises its discretion - in the sense of making choices about when, how and

\footnotetext{
${ }^{3}$ These concepts will be explored in more detail below. The HMRC Charter, introduced in section 92 of the Finance Act 2009, can be found at http://www.hmrc.gov.uk/charter/charter.pdf. As presently constituted it does not appear to give taxpayers any additional rights: see J. Whiting, "HMRC Charter Magna Carta the second?” [2009] BTR 616.

${ }^{4}$ Section 6 , Human Rights Act 1998.
} 
to what extent to make a claim for tax - all the time. No tax system as complex as the one in the UK could possibility operate without scope for some judgement around these decisions. This section discusses some areas in which these types of application of choice or discretion are used at present and outlines the issues that have arisen as to that use. The limits on HMRC in this connection are investigated further, in their constitutional context, in section 3, which assesses the protection available to taxpayers in this respect.

\section{Responsibilities of HMRC}

The functions of HMRC are set out in section 5 of the Commissioners for Revenue and Customs Act 2005 (CRCA), which vests HMRC with the responsibility for the "collection and management" of taxes. Section 9 then expands on this provision by giving HMRC the power to "do anything which they think (a) necessary or expedient in connection with the exercise of their functions, or (b) incidental or conducive to the exercise of their functions."

Section 51(3) of the CRCA provides that

"A reference in this Act, in an enactment amended by this Act or, subject to express provision to the contrary, in any future enactment, to responsibility for collection and management of revenue has the same meaning as references to responsibility for care and management of revenue in enactments passed before this Act.”

These words are designed to make clear that there was no intention to change the scope of the responsibility by the 2005 legislation, which was part of the Tax Law Rewrite project. $^{5}$ The wording of the legislation clearly gives HMRC considerable discretion but some limits have been applied by the case law and the previous case law still holds, unless overruled by subsequent cases or express statutory provisions. The limits imposed by the case law will be discussed below in this Part and further in Part 3 of this article. We shall start, however, by outlining some main areas in which discretion is utilised by HMRC and on which this article will focus.

HMRC may be said to apply its discretion in the following categories of case.

A. Discretion as to non-application of the law where its proper interpretation is agreed.

B. Discretion as to how to interpret the law.

C. Discretion in management of application of legislation and litigation

D. Hybrids of categories $A$ and $B$ or of categories $B$ and $C$.

This paper will focus on the above categories and in particular on two cases studies which investigate the difficulties of hybrid discretions under D. There are other instances of the operation of HMRC discretion ${ }^{6}$ but this paper will confine itself to

\footnotetext{
${ }^{5}$ Explanatory Notes to the CRCA 2005 at para. 46.

${ }^{6}$ For example, HMRC may have some discretion to produce secondary legislation, or regulations. This must clearly be intra vires the power given by Parliament to produce this legislation. For example see $R$ v IRC, ex parte Woolwich Equitable Building Society [1987] STC 654. The Inland Revenue (as the
} 
those above.

A. Discretion as to non-application of the law where its proper interpretation is agreed.

HMRC may decide not to enforce the law according to its agreed meaning.

There are various ways in which it has done this in the past and the primary methods are:-

i) published extra-statutory concessions

ii) waivers or deals with individual taxpayers or groups of taxpayers on a one-off basis.

i) Extra-statutory concessions

Extra-statutory concessions have been controversial since they were first introduced, and the attacks on them were described in an article by David Williams in $1979 .{ }^{7} \mathrm{He}$ reports that the existence of these concessions was first reported to the Public Accounts Committee ${ }^{8}$ in 1897. The Final Report of the Royal Commission on the Taxation of Income and Profit commented that it was 'a little disconcerting to find the statute law being amended by this special and selective process'. ${ }^{9}$ The practice increased during the Second World War, but peace time did not see the withdrawal of this device. Pressure resulted in an agreement to publish a list of extant concessions annually and this practice continues today. ${ }^{10}$ The judiciary sometimes accepted concessions as facilitating the operation of the tax system in a useful way but some judges were considerably more critical. Lord Reid, for example, rejected a concession on the grounds that 'administrative moderation ... is no substitute for legal clarity and precision.' 11

Williams questioned the practice of granting concessions and suggested that it was contrary to the 'rule of law.' He was commenting soon after a decision by Walton $\mathrm{J}$ in the case of Vestey $v$ IRC, ${ }^{12}$ whose words "One should be taxed by law, and not be untaxed by concession" were echoed famously by Lord Wilberforce in a subsequent return of that case. ${ }^{13}$ In fact that case concerned the use of unpublished administrative discretion to attempt to fill a gap in defective legislation and so did not necessarily outlaw the more established published extra-statutory discretions.

Since then there have been further clarifications regarding the scope of concessions which may be granted, most notably by the House of Lords in Wilkinson $v$ IRC. ${ }^{14}$ This

tax authority was then called) was held to have exceeded its powers in Regulations but Parliament subsequently enacted legislation o the same effect. For further discussion see S. Eden, "A tax on all blue-eyed persons” in M.Greggi (ed) Bridging the Sea (forthcoming).

${ }^{7}$ D. Williams, "Extra-Statutory Concessions”, [1979] BTR 137.

${ }^{8}$ This is a Committee of the House of Commons that still exists today.

${ }^{9}$ Cmd. 9474, para 240, cited in Williams op. cit. at p. 137.

${ }^{10}$ The August 2009 list may be found at http://www.hmrc.gov.uk/specialist/esc.pdf

${ }^{11}$ Bates v IRC [1969] AC 483,500 cited by Williams op. cit. at p.141.

${ }^{12}$ [1979] Ch. 177, 197.

${ }^{13}$ Vestey $v$ IRC [1980] A.C. 1148. This case, and in particular Lord Wilberforce's comments, are discussed in some detail further on below.

${ }^{14} R$ v IRC, ex parte Wilkinson [2005] UKHL 30 per Lord Hoffmann paras. 20-23 
case has caused HMRC to review all its concessions and to commence a programme of withdrawing some and legislating others that fall outside the scope of its discretion according to the views outlined by Lord Hoffmann. ${ }^{15}$

In Wilkinson Lord Hoffmann agreed with the well known statement of Lord Diplock in IRC $v$ National Federation of Self-Employed and Small Businesses Ltd ${ }^{16}$ that HMRC were granted "a wide managerial discretion as to the best means of obtaining for the national exchequer from the taxes committed to their charge, the highest net return that is practicable having regard to the staff available to them and the cost of collection."

He then continued:

"[t]his discretion enables the commissioners to formulate policy in the interstices of the tax legislation, dealing pragmatically with minor or transitory anomalies, cases of hardship at the margins or cases in which a statutory rule is difficult to formulate or its enactment would take up a disproportionate amount of parliamentary time... [i]t does not justify construing the power so widely as to enable the commissioners to concede, by extra-statutory concession, an allowance which Parliament could have granted but did not grant...”

This marks an outer limit beyond which concessions are ultra vires but presents us with a serious problem when it comes to the extent to which concessions can be binding on HMRC under the doctrine of legitimate expectation discussed in section 3 below. Under this doctrine a court may, through the medium of a public law remedy, judicial review, hold HMRC to be bound by a concessions and relaxations of enforcement procedures in some circumstances. The question of whether this applies in a case where it is outside the powers of HMRC to grant such a concession is one to which we shall return in part 4 below.

HMRC's current list of concessions states that:

"An Extra-Statutory Concession is a relaxation which gives taxpayers a reduction in tax liability to which they would not be entitled under the strict letter of the law. Most concessions are made to deal with what are, on the whole, minor or transitory anomalies under the legislation and to meet cases of hardship at the margins of the code where a statutory remedy would be difficult to devise or would run to a length out of proportion to the intrinsic importance of the matter.

The concessions described within are of general application, but it must be borne in mind that in a particular case there may be special circumstances which will need to be taken into account in considering the application of the concession. A concession will not be given in any case where an attempt is made to use it for tax

\footnotetext{
15 Treasury orders (secondary legislation) to enact concessions can be introduced under a power in section 160 of Finance Act 2008. Several documents discussing the withdrawal or enactment of concessions are now on the HMRC website. Many concessions are considered to be valid under the Wilkinson test and these will be retained. Where concessions are withdrawn and not enacted it is stated on the website that an appropriate period of notice will be given to allow taxpayers to review their affairs and there will be no retrospective effect of any change. It is questionable whether this can be binding in view of the above discussion.

${ }^{16}$ [1981] STC 260 (HL)
} 
avoidance."17 $^{17}$

The two points to note here is that it continues to be assumed that a valid concession may go beyond the law and that there is a major let out clause for HMRC in cases of "avoidance"- avoidance itself being a somewhat difficult term to define. This clearly impacts on the value of the concession, as we shall see below.

ii) Waivers and deals

In addition to generalised concessions, HMRC has a settled discretion within its powers of management under section 5 CRCA to reach agreements with individual taxpayers or groups of taxpayers. This was firmly established in Inland Revenue Commissioners $v$ National Federation of Self-Employed and Small Businesses Ltd ${ }^{18}$ and indeed it can easily be seen that without the ability to settle cases and decide whether to pursue particular issues it is not possible to run a tax system in a sensible way. The National Federation of Self-Employed case permitted the Inland Revenue, as it then was, to come to an agreement with unions and employers concerning a group of workers, wiping out past tax liabilities incurred as a result of evasion on the condition of future co-operation. The tax was probably impossible to collect in any event but this waiver was challenged as unreasonable by a group representing small businesses. The case made clear that there was no rule of equality in tax treatment that prevented such a deal in the UK and the majority also held that other taxpayers, including the small business group, had no locus to bring the case. In $R v \operatorname{IRC}$, ex $p$ $M F K{ }^{19}$, relying on the earlier case of Preston $^{20}$, the court confirmed that if the revenue authority agreed to forgo tax which might arguably be payable on a proper construction of the relevant legislation, it could be held to that representation under the doctrine of legitimate expectation developed as part of judicial review (discussed in Part 4 below) provided the taxpayer had made full disclosure.

There are limits to this, however, as shown in the case of Al Fayed. ${ }^{21}$ There are some deals which are ultra vires and therefore, it would seem, cannot bind the revenue authority. An unlawful use of its discretion cannot bind the revenue authority. The problem is to know what is unlawful, since it is permissible to forgo tax that might otherwise be collected in some a case like MFK but not in Al Fayed, where it was held that the Revenue had no power to contract with a taxpayer as to his future tax liability. This is discussed further in Part 4 below.

\section{B. Discretion as to how to interpret the law.}

It is clearly ultimately for the courts to decide on the proper meaning and application of legislation, but in practice there is considerable scope for HMRC to opine on the meaning of legislation. Unless and until HMRC's view is challenged in the courts it is likely that many taxpayers will rely on the HMRC interpretation and this is therefore a very powerful tool. The following devices are utilised:-

i) statements of practice, interpretations and press releases

\footnotetext{
${ }^{17}$ http://www.hmrc.gov.uk/specialist/esc.pdf

${ }^{18}$ [1981] 2 W.L.R. 722.

19 [1989] STC 896,

${ }^{20}$ [1985] STC 282

${ }^{21}$ Al Fayed v Advocate General for Scotland [2004] STC 1.
} 
ii) guidance booklets and guidance statements

iii) manuals written initially for revenue staff

iv) statutory and non-statutory clearances

i)- iii) Statements of Practice, guidance and manuals.

These various statements may be used to give a view on new legislation or areas where uncertainties and difficulties have arisen. They are often used to fill in the gaps where the legislation is drafted in broad terms, especially in the case of anti-avoidance legislation or where a term is used that is not defined in the legislation. There is increasing use of guidance in view of the desire to legislate in a broad fashion to escape the problems of complexity in legislation leading to creative compliance. ${ }^{22}$ At present this guidance is completely outside the legislative system as it is not contained in regulations (secondary legislation) but is simply issued by HMRC. ${ }^{23}$ As with extrastatutory concessions, and as discussed further below, published guidance is often qualified by caveats and may be very general in nature. The impact of those caveats on the value of the guidance is discussed further below.

Sometimes the guidance published by HMRC contains an element of concession that is categories A and B overlap. Given the indeterminacy of tax law the distinction between interpretation and the giving of a concession can be hard to discern. If there is a concessionary element there may the be a question mark over whether the guidance can found a legitimate expectation and this will be discussed further in ration to the Gaines-Copper case in part 5.

HMRC also publishes manuals, primarily for the guidance of its own staff. These are now published on the internet, however, and have become a valuable and popular starting place for practitioners researching tax questions. This is now encouraged by HMRC and they are beginning to put certain forms of guidance directly into the manuals, where they expect taxpayers and their advisers to consult them. The manuals raise many of the same questions as published guidance. In addition they are frequently amended, and this can give rise to real difficulties in keeping track of changes, since amendments are not marked on the face of the amended manual and the old version is removed from the HMRC website.

\section{iv) Clearances}

There is no general system of clearances or rulings in the UK, although some legislative provisions contain specific clearance application provisions. ${ }^{24}$ Unless such a specific provision is included the taxpayer may apply for clearances only in limited circumstances, at present. These are set out in Code of Practice 10 for general customers.

For business customers there is a more extensive clearance service described on the HMRC website. ${ }^{25}$ For this group, HMRC aims to provide clearances on areas of material uncertainty arising within four Finance Acts of the introduction of any new legislation and on legislation older than last four Finance Acts where there is material

\footnotetext{
${ }^{22}$ See Part 5 below.

${ }^{23}$ See the discussions of the guidance on residence and the guidance on section 16A of the Taxation of Chargeable Gains Act 1992 discussed in Part 5 below.

${ }^{24}$ For example section 748 Corporation Tax Act 20101 (transactions in securities).

${ }^{25}$ http://www.hmrc.gov.uk/cap/links-dec07.htm
} 
uncertainty around the tax outcome of a real issue of commercial significance to the business itself, determined by reference to the scale of the business and the impact of the issue upon it . The website states that

"Clearances do not alter the tax treatment but simply give you HMRC's view of what the correct tax treatment is."

Non-statutory clearances under this practice are therefore not binding on HMRC in a strict sense but would bind HMRC under the doctrine of legitimate expectation provided the taxpayer fell squarely within the clearance given and had made all the facts and details clear to HMRC under the MFK doctrine, discussed above.

\section{Discretion in management of application of legislation and litigation}

(i) Codes of Practice are used by HMRC that set out the way in which they will conduct investigations and enquiries, when and how it will offer advice and provide information and how it will conduct consultations on proposed changes to the law. ${ }^{26}$ There is also a litigation and settlements strategy which guides the way in which disputes are dealt with. ${ }^{27}$

The Codes of Practice create self-imposed duties on HMRC but in some cases also mean that they will apply their discretion, for example by not exacting the full penalty available under the law where voluntary disclosure of irregularities is made. Discretion is also applied as to when to pursue a case through the courts and when to settle.

(ii) Resource allocation and risk rating are management tools which may employ a degree of discretion. Resource allocation is very clearly recognised to be the central area where HMRC needs to have scope to manage in a cost efficient way. ${ }^{28}$

HMRC may decide the level of resource to devote to any given taxpayer in scrutinizing tax returns and making enquiries. There is an increasing (and entirely sensible) tendency to base such decisions on profiling of taxpayers and risk-rating. ${ }^{29}$ In relation to large businesses, for example, this has been formalized in the UK in a risk rating process which categorises each business as being low risk or not and deciding on its treatment accordingly. ${ }^{30}$ The process of assigning the risk rating involves the application of criteria the devising of which can itself be a process involving the application of discretion, since the consequences of categorization can

\footnotetext{
${ }^{26}$ The Codes of Practice can be found at http://www.hmrc.gov.uk/leaflets/c11.htm

27 HMRC Litigation and Settlements Strategy - this can be found at http://www.hmrc.gov.uk/practitioners/lss-intro.htm

${ }^{28}$ Inland Revenue Commissioners v National Federation of Self-Employed and Small Businesses Ltd [1981] 2 W.L.R. 722.

${ }^{29}$ This is a worldwide trend- see for example Fiscalis Risk Management Platform Group, Compliance Risk Management Guide for Tax Administrations, (European Commission, 2010)

http://ec.europa.eu/taxation_customs/resources/documents/common/publications/info_docs/taxation/ris k_managt_guide_en.pdf

${ }^{30}$ HMRC, Tax Compliance Risk Management Process (May 2009), (TCRM) available at: www.hmrc.gov.uk/manuals/tcrmanual/index.htm (accessed August 29, 2010).
} 
be considerable. Categorization has been used quite explicitly to influence the behaviour of the taxpayer. In some documents there are suggestions that HMRC will only allocate a low risk rating to taxpayers who do not challenge HMRC's interpretation of the law or even those who use acknowledge loopholes or anomalies in the law. ${ }^{31}$ In this way, risk rating, whilst initially appearing to be a purely administrative device can become a significant application of discretion, even going so far as to attempt to influence taxpayers to be over-complaint. ${ }^{32}$

\section{Hybrids of categories A and B or of categories B and C.}

Where a discretion as to how to manage resources or interpret legislation is interlaced with concessionary treatment we have a hybrid of the above categories. The concession may be an integral part of the treatment applied by HMRC and may be a deliberate relaxation or simply the unintended consequence of a particular interpretation. If the validity of the concessionary part of guidance is in question, however, then this might undermine the guidance entirely. Both the case studies in section 5 explore this issue in more detail.

\section{CONSTITUTIONAL LIMITS ON HMRC DISCRETION}

This part provides some constitutional background to the analysis. In particular, it examines the constitutional principles which determine that amount of discretion which can be vested in HMRC.

\section{The Framework Dictated by the Supremacy of Parliament Principle}

We start by examining the constitutional principles which determine how much discretion may be granted to HMRC by legislation. The traditional starting point to answering this question is the doctrine of supremacy of parliament principle. According to this principle parliament enjoys "the right to make or unmake any law whatever: and, further, that no person or body is recognised by the law of England as having a right to override or set aside the legislation of parliament." ${ }^{33}$ It follows that,

\footnotetext{
${ }^{31}$ See TCRM ibid. The Assessment Indicators in Annex B include the significant use of loopholes or anomalies in the law to minimise taxes or duties, yet these may be based on an agreed correct interpretation of the law. Also included as indicators of high risk are frequent tax planning that requires disclosure to HMRC or innovative interpretation of tax law; choice of analysis because it has the most tax-advantageous potential outcome and regular submission of requests for clearances or making of voluntary disclosures which are not in accordance with HMRC guidance .

32 Another example of this approach is the Code of Practice on Taxation of Banks http://customs.hmrc.gov.uk/channelsPortalWebApp/channelsPortalWebApp.portal?_nfpb=true\&_page Label=pageVAT_ShowContent\&propertyType=document\&columns=1\&id=HMCE_PROD1_030008. This was to have been introduced in December 2009 although as it is voluntary and not statutory there is no information available about its take up rate. It states that "the Government expects that banking groups, their subsidiaries, and their branches operating in the UK, will comply with the spirit, as well as the letter, of tax law, discerning and following the intentions of Parliament”. For further discussion see J. Freedman, "Tax Risk Management and Corporate Taxpayers - International Tax Administration Developments" in A. Bakker and S. Kloosterhof (eds) Tax Risk Management. From Risk to Opportunity (IBFD, 2010).

${ }^{33}$ A. V. Dicey, Introduction to the Study of the Law of the Constitution - first published in 1885 in London by Macmillan. Bradley and Ewing have explained that “...in the United Kingdom the legislative supremacy of Parliament appears to be the fundamental rule of constitutional law and this
} 
theoretically at least, any law may be enacted by means of a simple majority in Parliament, including a law that accords extremely broad discretionary powers to the revenue authorities. Any law or even constitutional principle which stands in the way of conferring such discretion, including the Bill of Rights Act $1689,{ }^{34}$ the Rule of Law, the Human Rights Act 1998 or even, ultimately, in theory at least, any aspect of EU Law, ${ }^{35}$ may be overcome by a simple Act of Parliament. ${ }^{36}$

The above analysis follows the traditional understanding of the doctrine of parliamentary supremacy. Some senior judges have intimated that this doctrine would need to be revisited in extreme situations. ${ }^{37}$ This suggests that UK courts might intervene if, for example, a statute breaches the rule of law in an extreme fashion. Whilst this would be considered a fairly uncontroversial and unremarkable process in many jurisdictions, so deeply entrenched is the doctrine of parliamentary supremacy within the British constitutional system that fellow senior judges and commentators have dismissed this possibility out of hand. ${ }^{38}$

The supremacy of parliament principle thus dominates the constitutional landscape in the UK. A law which simply states "HMRC may determine the tax to be collected from individuals" would thus be legal albeit "unconstitutional" in the sense that it contravenes well established constitutional principles. ${ }^{39}$ Such a law might require the specific repeal of Acts such as the Bill of Rights Act 1689 and the Human Rights Act 1998, but this may be done by the mere expedient of an Act of Parliament passed by simple majority.

The overpowering strength of the supremacy of parliament principle might seem to leave the other relevant constitutional principles, which we discuss in 3.1.2. and which what we may refer as the "remaining constitutional principles" for ease of reference, with little room to protect taxpayers. Whilst true in theory, this is less so in practice. Indeed, these constitutional principles in practice protect taxpayers in two important ways.

supremacy includes power to legislate on constitutional matters. In so far as constitutional rules are contained in earlier Act, there seems to be no Act which Parliament could not repeal or amend by passing a new Act. The Bill of Rights of 1689 could in law be repealed or amended by an ordinary Act of Parliament.” Bradley and Ewing, Constitutional and Administrative Law, 14th ed., (Longman, 2008) at p. 57.

${ }^{34}$ Note that article 9 of the Bill of Rights 1689 was amended by section 13 of the Defamation Act 1996.

${ }^{35}$ EU Law represents a special case and shall be discussed further on. The point here is that if any aspect of EU Law were to stand in the way of Parliament, Parliament could ultimately repeal the European Communities Act 1972 and take the necessary steps, all by means of a simple Act of Parliament, to end the UK's membership of the EU, although since this involves international treaties and institutions this would obviously be very complex in practice.

${ }^{36}$ On the European Communities Act 1972 see Thoburn v Sunderland City Council [2002] EWHC 195, [2003] QB 151; on the Human Rights Act 1998 see Watkins $v$ Secretary of State for the Home Department and others, [2006] UKHL 17, [2006] 2 A.C. 395.

${ }^{37}$ See Lord Woolf, 'Droit Public - English Style', [1995] PL 57; Taylor v New Zealand Poultry Board [1984] 1 NZLR 394 at 398 per Lord Cooke and $R$ (Jackson) $v$ A-G [2005] UKHL 56 at [102] per Lord Steyn.

${ }^{38}$ Lord Bingham, “The rule of law and the sovereignty of Parliament”, KLJ 2008, 19(2), 223. See also Richard Ekins, 'Acts of Parliament and the Parliament Acts', LQR 2007, 123(Jan), 91-115 and J. Goldsworthy, "Is Parliament Sovereign? Recent Challenges to the Doctrine of Parliamentary Sovereignty” (2005) 3 New Zealand Journal of Public and International Law 7.

${ }^{39}$ Bradley and Ewing, op. cit. at p. 26. 
Firstly, the "principle of legality" enjoins courts to interpret statutes in a manner that ensures compatibility with basic constitutional rights and principles, unless these are overridden by express language or clear and necessary implication. ${ }^{40}$ This is an interpretative presumption which allows courts to depart from the natural meaning of the statute in order to ensure compatibility with such constitutional rights and principles, unless legislation expressly or by clear and necessary implication runs counter to them. ${ }^{41}$ Lord Rodger explained that courts employ this presumption "because the substance of the rule is perceived to be so important that Parliament must squarely confront what it is doing when it interferes with it and must accept the political cost. ${ }^{, 42}$ In $R v$ Secretary of State for the Home Department Ex p. Simms Lord Steyn described the principle of legality as a constitutional principle and it has been held to apply to both constitutional principles arising from the common law, as well as those arising from statutes, such as the Bill of Rights $1689 .{ }^{43}$ As shall be seen further on, a stronger version of the principle of legality applies in the context of the Human Rights Act 1998. The principle of legality is one that comes into play when courts are asked, by means of an application for judicial review, to determine whether a particular act by HMRC exceeded the vires conferred upon them by widely drafted discretionary powers. The principle of legality will enjoin a court to narrow the ambit of the discretion if necessary to ensure conformity with the remaining constitutional principles.

The remaining constitutional principles also protect taxpayers in a second way. Although they can be breached by a simple Act of Parliament with no apparent redress being available, serious breaches of these principles would rouse political clamour, meaning that politicians have a vested interest in treading carefully in such areas. Egregious breaches could lead to a potentially fatal political backlash and are thus less likely to arise. More subtle breaches of these principles do not raise such clamour, however, and thus constitute a real and pernicious possibility. This makes it all the more important to identify the boundary established by these principles in a clear a fashion as possible. If they are to be breached, this should be done knowingly and on the back of reasoned consideration.

Before leaving the topic of Parliamentary sovereignty is should be noted that it might at first appear strange to assert Parliamentary sovereignty in a system where the doctrine of judicial precedent plays such a strong role. This is, however, entirely consistent with the notion of Parliamentary sovereignty since the role of the judges is to ascertain the intention of Parliament . Naturally if Parliament dislikes any resulting interpretation it may pass amending legislation - thus the sovereignty is maintained in theory at least.

\section{Other Constitutional Principles}

The conclusion reached in the previous section is that whilst the UK Parliament may enact any law by means of a simple majority, including one that confers untold

\footnotetext{
${ }^{40}$ P. Sales, 'A comparison of the principle of legality and section 3 of the Human Rights Act 1988' [2009] LQR 598.

${ }^{41}$ Regina $v$ Secretary of State for the Home Department, Ex parte Pierson [1998] A.C. 539.

${ }^{42}$ Watkins $v$ Secretary of State for the Home Department and others, [2006] UKHL 17, [2006] 2 A.C. 395.

${ }^{43}$ Thoburn v Sunderland City Council [2002] EWHC 195, [2003] QB 151.
} 
discretion upon HMRC, in practice political considerations and constitutional principles do provide protection for taxpayers. The two main constitutional principles that are of interest for our purpose are Article 4 of the Bill of Rights 1689 ("Article 4") and the rule of law. The Human Rights Act 1998 and EU law place further limitations on the conferral of discretionary power on HMRC. We can look at each in turn.

Article 4 of the Bill of Rights $1689^{44}$

Article 4 provides:

"That levying money for or to the use of the Crown by pretence of prerogative, without grant of Parliament, for longer time, or in other manner than the same is or shall be granted, is illegal”

Article 4 is a potent constitutional principle. It has been used by courts and has had an important effect in a variety of contexts. Article 4 was invoked to show that the courts could not have developed a judicial anti-avoidance rule. ${ }^{45}$ This constitutional principle, the judges argued, would be violated by a judicial anti-avoidance rule, as this would be tantamount to tax being imposed by the courts rather than Parliament. The anti-avoidance rule that had appeared to surface and take shape from Ramsay ${ }^{46}$ onwards was thus recast as an instance of statutory interpretation. Article 4 played an equally decisive role in the creation of a remedy in restitution for tax paid under an ultra vires demand. In Woolwich Equitable Building Society $v$ Commissioners of Inland Revenue, ${ }^{47}$ Lord Goff held that full effect can only be given to the principle enshrined in Article 4, "if the return of taxes exacted under an unlawful demand can be enforced as a matter of right". ${ }^{48}$ Furthermore, this principle has been expanded to cover cases in which tax or other levy has been wrongly exacted by the public authority not because the demand was ultra vires but also if the authority has misconstrued a relevant statute or regulation. ${ }^{49}$ This potent constitutional principle can thus both curtail or assist the development of a judge-made rule.

\footnotetext{
44 An Act Declaring the Rights and Liberties of the Subject and Settling the Succession of the Crown 1688 c.2 1_Will_and_Mar_Sess_2 (known as The Bill of Rights) emerged from the "Glorious Revolution” of 1688-89, which culminated in the exile of King James II and the accession to the throne of William of Orange and Mary. Its intentions were: to depose James II for misgovernment; to determine the succession to the Throne; to curb future arbitrary behaviour of the monarch; and to guarantee parliament's powers vis a vis the Crown, thereby establishing a constitutional monarchy- see House of Commons Library note SN/PC/0293 (2009)

http://www.parliament.uk/documents/commons/lib/research/briefings/snpc-00293.pdf

${ }^{4}$ MacNiven v. Westmoreland [2001] UKHL 6, [2001] S.T.C. 237, at [29] per Lord Hoffmann and The Collector of Stamp Revenue v. Arrowtown Assets Limited [2003] HKCFA 46, at [105] per Lord Millett.

${ }^{46}$ WT Ramsay Ltd v IRC [1981] STC 174

${ }^{47}$ [1993] AC 70.

${ }^{48}$ In the case Kingstreet Investments Ltd. v. New Brunswick (Finance), 2007 SCC 1, [2007] 1 S.C.R. 3. the Canadian Supreme Court held that the unjust enrichment analysis is ill-suited to deal with the issues raised by ultra vires taxes. Instead, it argued that in such a case taxpayers have recourse to a remedy as a matter of constitutional right. The constitutional principle relied upon by the Canadian Supreme Court as a basis for this remedy, enshrined in sections 53 and 90 of the Constitution Act 1867, is similar to Article 4.

${ }^{49}$ See Lord Goff obiter dictum in Woolwich which seems to have been accepted in British Steel plc $v$ Customs and Excise Comrs [1997] 2 All E.R. 366.
} 
Article 4 has also been determinative in dealing with questions which are nearer to that under consideration in the present section. In A-G $v$ Wilts United Dairies $L_{t}{ }^{50}$ and Commissioners of Customs and Excise $v$ Cure \& Deeley Ltd $^{51}$ Article 4, in conjunction with the principle of legality, allowed the court to find that a statutory provision delegating power to an administrative agency could not be deemed to have included the power to raise taxes. If Parliament intended to empower administrative agencies to impose taxes, counter to the constitutional principle embodied in Article 4, it must do so expressly. As this was not done in these two cases the court concluded that the power was not implied and, therefore, the imposition of taxes by the agencies was ultra vires. Article 4 therefore clearly protects against the selfarrogation of taxing power by the executive.

Article 4 thus remains an important principle of British constitutional law. The question we must now ask is how it affects the conferment of discretionary powers upon HMRC. Would the principle be breached if a considerable amount of discretion were to be vested expressly in HMRC as this would be tantamount to tax being imposed by a body other than Parliament? Or would the fact that the power is vested in HMRC by Parliament itself satisfy Article 4? We can start by considering an extreme case. A law which simply stated "HMRC may, at its discretion, determine the tax to be collected from individuals" might be thought to be in line, technically, with Article 4 as the taxing power vested in HMRC would be granted by means of an Act of Parliament. The principle of legality would mean that the courts would do all they could to interpret such a power as narrowly as possible but ultimately, the fact remains that the supremacy of parliament doctrine would ensure that such a law, as long as it is expressed in clear and unequivocal language would have to be respected by the courts.

Less extreme cases present greater difficulty. We can start by considering how the general managerial discretion conferred upon HMRC by section 5 of the Commissioners for Revenue and Customs Act 2005 might be narrowed by the principle of legality to ensure conformity with Article 4. The principle of legality might narrow this provision by excluding discretionary powers which are tantamount to tax being imposed by HMRC rather than Parliament. Whilst it is clear that HMRC should not seek to collect taxes that are not imposed by statute, what tax a statute actually imposes is often less clear. Indeed, it is often the case that two (or more) tenable interpretations exist, according to one of which a transaction is taxed, and according to another it is not. ${ }^{52}$ In that situation, HMRC should of course be free to pursue the interpretation that it prefers. If, however, both alternatives are based on arguable cases, it would seem to be outside the discretion of HMRC to decide that one of those interpretations is 'unacceptable' and not the view of Parliament, since this a matter for the courts to ascertain, as explained above.

It follows from the above that limitations are equally placed by Article 4 on Discretion C - namely the discretion in the management of the application of legislation and litigation. The reasoning made thus far implies that Article 4 narrows

\footnotetext{
${ }^{50}$ (1921) 37 TLR 884 confirmed on appeal by the House of Lords (1922) 38 TLR 781.

51 [1962] 1 Q.B. 340.

52 One ought not to forget that eminent members of the judiciary have frequently disagreed on the interpretation of a taxing provision and hence the outcome of a tax dispute.
} 
HMRC's discretion here. Whilst demanding tax based on a tenable interpretation of the law is obviously within HMRC's powers, imposing costs on taxpayers who choose to follow an interpretation of the law that is tenable but different to that held by HMRC is not, although of course if HMRC decides to litigate the case to test its views that is a different matter. But simple declarations of an interpretation do not establish that this is the law and so should not be used to penalize the taxpayer who disagrees with the declaration on reasonable grounds.

A second and equally difficult issue arises in the context of provisions which do not vest HMRC with broad discretionary powers yet are worded so broadly that they require considerable discretion by HMRC to be applied. Does Article 4 affect these provisions? Could they ever be deemed to be so broad as to require de facto legislation by HMRC contrary to Article 4? We are, once again, here dealing with Discretions A, B and C. One might think that Parliamentary Supremacy dictates that courts must always interpret such a provision as vesting HMRC with the discretion necessary to give effect to it or that HMRC's general discretion would empower it to give effect to the provision. In Vestey $v$ IRC, ${ }^{53}$ Lord Wilberforce suggested otherwise.

Vestey concerned assessments to tax made upon beneficiaries under a discretionary trust. The relevant statutory provision was so broadly drawn that interpreted strictly it arguably allowed HMRC to assess a single beneficiary on the basis of the total income of the settlement in the year of apportionment of the capital sums, and this regardless of the amount of benefit actually received by him. ${ }^{54}$ HMRC argued that in such cases they have a discretion which enables them to assess one or more or all of the individuals in such sums as they think fit, the only limitation upon this discretion being that the total income may not be assessed more than once. Lord Wilberforce described this as "a remarkable contention." ${ }^{55}$ He also stated:

“Taxes are imposed upon subjects by Parliament. A citizen cannot be taxed unless he is designated in clear terms by a taxing Act as a taxpayer and the amount of his liability is clearly defined. A proposition that whether a subject is to be taxed or not, or, if he is, the amount of his liability, is to be decided (even though within a limit) by an administrative body represents a radical departure from constitutional principle. It may be that the revenue could persuade Parliament to enact such a proposition in such terms that the courts would have to give effect to it: but, unless it has done so, the courts, acting on constitutional principles, not only should not, but cannot, validate it.

The commissioners have, I gladly accept, done their best to devise a system which is workable and reasonably fair. But whatever system they might devise lacks any legal basis. I must regard this case therefore as one in which Parliament has attempted to impose a tax, but in which it has failed, in the case of discretionary beneficiaries, to lay down any basis on which it can be assessed or levied. In the absence of any such basis the tax must fail.”56

\footnotetext{
53 [1980] A.C. 1148.

${ }^{54}$ See p. 1193.

${ }^{55}$ At p. 1171.

${ }^{56}$ Note also that Lord Wilberforce states that if the correct interpretation of the section is that argued for by HMRC he would conclude "that no method for levying the tax in such cases has been prescribed by Parliament, that this gap cannot be filled by administrative decision and the assessments of it fail.”
} 
Lord Wilberforce does not mention Article 4 expressly but his sentiments reflect its contents. Whilst the supremacy of parliament means that Parliament can enact statutes which require a large degree of discretion to be exercised by HMRC and courts must validate them, it must do so in clear and unequivocal terms. If the laws are not clear in conferring this discretion onto HMRC courts will simply assume that Parliament did not intend overturning Article 4. Interestingly, Lord Wilberforce was unwilling to interpret HMRC's general discretion as including discretion to give effect to this statutory provision or to interpret the relevant statutory provision as implying the necessary discretion to give effect to it. The presumption that Parliament would not want to overturn Article 4 is too strong to allow either. Before doing so, Lord Wilberforce was prepared to simply find that the statutory provision "failed". 57

This leaves open the task of determining how much discretion a provision requires for its application before it runs into the problems faced by the provision in Vestey. Or, viewed from a different perspective, how vague can a taxing provision be? This is clearly a matter which ought to be taken into consideration when designing new tax legislation. If a provision requires discretion of the proportions discussed in Vestey, it is necessary to ensure that Parliament vests HMRC in a clear and unequivocal manner with the discretion necessary to apply it unless it is to run the risk of being deemed by a court to have "failed". Of course, it is not altogether apparent from Lord Wilberforce speech how "clear" a conferment of discretion on HMRC need to be. In any event, the provision at issue in Vestey was pretty extreme. Crucially, it provided no indication on how HMRC ought to be narrow its application in practice. We must thus conclude that a provision would have to necessitate a remarkable amount of discretion before it could be deemed to have "failed" on these grounds.

\section{The Rule of Law}

The rule of law is generally viewed as one of the main pillars of the British Constitution. ${ }^{58}$ That said, it has been interpreted in different ways by constitutional experts as well as legal philosophers, and, in keeping with this trend, no definition was attempted when it made its first appearance in a statute in $2005 .^{59}$

One of the earliest proponents of the rule of law was Dicey in his Introduction to the Study of the Law of the Constitution. ${ }^{60}$ His definition of the rule of law is in part contentious but his inclusion of the absence of arbitrariness, in that government should govern by known rules rather than by whim or discretion, is widely accepted. ${ }^{61}$ Tomkins argues that in English public law the rule of law has at its core a simple and clear meaning - that the executive may do nothing without clear legal authority first permitting its actions. This can be seen as the basis of the legal principle of judicial review, discussed below. ${ }^{62}$

\footnotetext{
(at p. 1179).

${ }^{57}$ See also Customs and Excise Commissioners v Top Ten Promotions Ltd [1969] 1 WLR 1163.

58 See A. V. Dicey, op. cit.

${ }^{59}$ Constitutional Reform Act 2005, s.1.which states that the Act does not adversely affect-
}

(a) the existing constitutional principle of the rule of law, or (b)the Lord Chancellor's existing constitutional role in relation to that principle.

${ }^{60}$ Op. Cit.

${ }^{61}$ A. Tomkins, Public Law, (OUP, 2003), at p. 22.

62 Ibid. p. 78. 
The legal philosopher Raz puts forward a slightly different formalist conception of the rule of law and argues that the basic intuition from which the rule of law doctrine derives is "the law must be capable of guiding the behaviour of its subjects". ${ }^{63}$ A number of principles follow from this concept, which Raz, Fuller and others have suggested over the years. The principles that are directly relevant to the issue discussed in this paper appear fairly uncontroversial and the first overlaps with the public law concept described above. That is that the lives of individuals should be governed by law and not by administrative discretion.

The other principles expounded by Raz include, more generally, that the law should be clear enough to allow individuals to regulate their affairs in advance. Thirdly, the exercise of governmental authority directly affecting individual interests must rest on legitimate foundations. ${ }^{64}$ Fourthly, the final determination of the meaning of law should be made by an independent third party. This last principle requires some elaboration. If a law were to be interpreted by its drafter, he might give it a meaning that is in line with his subjective intention in drafting it, but which cannot be apparent to anyone else upon reading the legislation. Therefore, individuals would not be able to regulate their affairs in advance, as demanded by the rule of law, because they would not have access to the meaning of the law as it will be eventually interpreted by the drafter.

Whilst fairly uncontroversial, these principles derived from the rule of law do not provide precise prescription. Take the first two principles noted above. A law stating "HMRC may, at its discretion, determine the tax to be collected from individuals" would clearly breach the first two principles dictated by the rule of law. Under such a law individuals' lives would be governed by discretion and not law, and its lack of clarity would not allow individuals to regulate their affairs in advance. On the other hand, it is well understood that some administrative discretion is not only useful but desirable, and that some vagueness in law is unavoidable. ${ }^{65}$

To this extent it would appear that the rule of law will primarily serve as a general guide on the framework the tax system should follow and aspire to and to protect against serious breaches. It will be used less frequently in calibrating specific aspects of the tax system such as the amount of discretion that ought to be vested in HMRC or how general the wording of a law may be. On the other hand, situations may arise when it provides specific prescription and where, a court interprets HMRC's general discretionary powers to be narrowed or affected by rule of law considerations. We can take a situation which is currently causing some controversy as an example.

Some recent initiatives by HMRC, such as risk rating for large businesses ${ }^{66}$ and a Code of Practice for Banks ${ }^{67}$ seek to change attitudes towards tax avoidance by

\footnotetext{
${ }^{63}$ J. Raz, 'The Rule of Law and its Virtue’, reprinted in The Authority of Law, $2^{\text {nd }}$ ed., (OUP, 2009), at p. 214.

${ }^{64}$ Halsbury’s Laws of England, Volume 1(1) (2001 Reissue)

${ }^{65}$ T. Endicott, “The impossibility of the rule of law” [1991] Oxford Journal Legal Studies 19(1).

${ }^{66}$ See the discussion under the introduction to category $\mathrm{C}$ in Part 2 above.
}

67 HMRC, A Code of Practice on Taxation for Banks, December 2009 http://www.hmrc.gov.uk/pbr2009/tax-banks-supp-0040.pdf It is believed that few if any banks have actually signed up to this but it indicates the way in which HMRC is attempting to exert pressure on taxpayers to alter their behaviour. 
putting pressure on taxpayers to follow what HMRC consider to be the 'spirit' of the law, even though this may not be the way in which the courts would interpret the legislation in question. These can be criticized as potentially undermining the rule of law. If HMRC attempts to impose its view of what is acceptable, even if there is an alternative tenable interpretation of the law, then arguably they are going further than pure interpretation and management and so are exceeding their clear legal authority. ${ }^{6}$ This concern was raised in connection with the Bank Code by the Financial Markets Law Committee. ${ }^{69}$

Of course it is true that the taxpayer may always appeal to the courts in such a case, but the aim of HMRC is to impose 'persuade' the taxpayer to pay tax according to HMRC's view of the law without having to deal with the matter through the courts, by increasing the cost and burden of those taxpayers choosing to adopt their own interpretation of the law, even though that might be an arguable interpretation. There is a point here at which reasonable management of the tax system may tip over into an unwarranted attempt to act without clear legal authority..

\section{Human Rights Act 1998}

A major part of the European Convention on Human Rights (ECHR) was incorporated into UK law by the Human Rights Act 1998. The Supremacy of Parliament principle however means that a domestic court may not strike down primary legislation which contravenes the ECHR. Instead protection through the courts is afforded by means of three other mechanisms. Firstly, domestic courts will try to interpret legislation consistently with the ECHR. ${ }^{70}$ As noted, this is similar to the principle of legality but stronger, in that courts can go even further in interpreting statutes to ensure conformity with the ECHR. ${ }^{71}$ Secondly, if this is not possible, a superior court may declare legislation to be incompatible with the ECHR, in which case the Government may make a remedial order removing the incompatibility from the statute. ${ }^{72}$ Parliament, however, might simply choose not to alter the offending legislation meaning that "[t]he constraints upon its [i.e. the HRA's] exercise by Parliament are ultimately political, not legal."73 A third protection is provided by Article 6 of the HRA which requires public authorities to adhere to the ECHR, and which gives courts the power to strike down any act which does not. In other words, the rights set out in the ECHR can be employed as grounds for judicial review, their infringement becoming a ground of illegality.

\footnotetext{
${ }^{68}$ The authors have investigated risk rating for large businesses further J. Freedman, G. Loomer and J. Vella, ‘Corporate Tax Risk and Tax Avoidance: New Approaches', (2009) BTR, 74-116. See also Freedman, "Tax Risk Management and Corporate Taxpayers - International Tax Administration Developments" op. cit.

${ }^{69}$ Financial Markets Law Review Committee, Issue 146 - Proposed HMRC Code, October 2009 http://www.fmlc.org/papers/Issue1460ct09.pdf

${ }^{70}$ Article 3 of the Act.

${ }^{71}$ See $R$ v IRC, ex parte Wilkinson [2005] UKHL 30. Therefore rights protected by means of the ECHR may only be overturned by express language or necessary implication to the contrary, as courts presume that even the most general words were intended to be subject to the basic rights of the individual. See also Regina $v$ Secretary of State for the Home Department, Ex parte Pierson [1998] A.C. 539.

${ }^{72}$ Articles 4, 5 and 10 of the Act.

${ }^{73}$ Regina $v$ Secretary of State for the Home Department, Ex parte Pierson [1998] A.C. 539 per Lord Hoffmann.
} 
Despite the above, there appear to be limited opportunities for these mechanisms to be invoked in narrowing HMRC's discretionary powers discussed in this paper. The main substantive right to which appeal could be made, Article 1 of Protocol 1, protects the right to property. This includes the protection against deprivation of one's possessions except in the public interest and subject to the conditions provided for by law and by the general principles of international law. It explicitly does not impair the right of a State to enforce such laws as the State deems necessary to secure the payment of taxes. Article 14 could also come into play in this context. It provides that the enjoyment of the rights set out in the convention shall be secured without discrimination.

Legislation conferring discretionary powers could violate Article 1 of Protocol 1 and Article $14 .^{74} \mathrm{~A}$ judicial review application could also be brought on the grounds that HMRC have violated these articles whilst exercising their discretionary powers. Examples might include the use of discretionary powers in a discriminatory manner contrary to Article 14 or demanding tax that is clearly not required at law and thus contrary to Article 1 of Protocol 1. It has been opined, however, that it is debatable whether the ECHR could provide a ground for redress in the event that HMRC choose not to apply published practice or to respect an undertaken given after full disclosure. $^{75}$

\section{EU Law}

EU membership presents a number of challenges to the traditional UK constitutional order. Firstly, EU institutions enact rules enjoying direct effect in the UK. Secondly, EU law is superior to domestic law meaning that UK courts must set aside UK legislation which is inconsistent with EU law, whether or not the UK legislation was enacted before or after the relevant EU law. From the UK perspective, ${ }^{76}$ the relationship between UK and EU law is governed by the European Communities Act 1972 and therefore it is this Act which allows for these breaks from traditional constitutional principles. It follows that the UK Parliament could, at any time, repeal this Act and bring an end to the UK's membership of the EU.

Direct taxation falls within the competence of Member States; nevertheless EU law can affect HMRC's discretionary powers in an indirect manner in this field. UK direct tax law is to be set aside to the extent that it breaches the fundamental freedoms protected by EU law. This would appear to mean that legislation purporting to vest HMRC with discretionary powers breaching these freedoms would be set aside. Similarly, a judicial review action could be brought against HMRC to the extent that they utilize their discretion in a manner inconsistent with the freedoms.

\footnotetext{
${ }^{74}$ For example a law which grants HMRC the discretion to decide whether a tax is to be imposed on either men or women.

${ }^{75}$ Natalie Lee (gen ed), Revenue Law - Principles and Practice, 28th ${ }^{\text {th }}$ ed., (Bloomsbury, 2010 ), p. 1532.

${ }^{76}$ EU member states and the EU institutions have divergent views on the question of supremacy of parliament. See P. Craig and G. De Burca, EU Law: Text, Cases and Materials, $4^{\text {th }}$. ed., (OUP, 2007), chapter 10.
} 


\section{JUDICIAL REVIEW AND LIMITS PLACED BY CASE LAW ON HMRC DISCRETION}

The constitutional principles examined in section 3 determine how much discretion may be vested in HMRC. They also, to some extent, underpin judicial review, a process through which administrative discretion is kept under check. Whilst assessing HMRC's exercise of its discretionary powers through judicial review, the courts have probed, set limits on and thus defined the scope of HMRC's discretionary powers.

\section{Judicial Review}

Judicial review provides one avenue for controlling administrative actions. It has been described as

" a central control mechanism of administrative law (public law) by which the judiciary take the historic constitutional responsibility of protecting against abuses of power by public authorities" 77

It is a procedure through which courts, on the demand of individuals, assess administrative actions. The case law has classified the grounds under three general heads: illegality, irrationality (or unreasonableness) and procedural impropriety. ${ }^{78}$ Each of these grounds can be subdivided into further, more specific grounds, such as abuse of power. The categories are not mutually exclusive and the considerations to be born in mind under them may even clash, as seen below.

Judicial review can thus provide control over the use of discretion, in that it allows individuals to challenge actions on the grounds that they were beyond the ambit of the relevant authority's discretionary powers, or, whilst within the authority's discretion they were taken on the basis of irrelevant considerations, for improper purposes or following inadequate procedures and so on. It does not, however, allow an appeal on the merits of a decision, as a court cannot substitute its decision for that of a public authority. In fact, whilst unreasonableness is a ground for review, it denotes a level of unreasonableness of outrageous proportion, such that no reasonable person could ever take it (known as Wedensbury unreasonableness after the case in which the test was established). ${ }^{79}$

The ground of illegality, and the doctrine of legitimate expectation developed as part of the judicial review jurisprudence, are of particular interest in the context of the discretionary powers discussed in this paper. The ground of illegality allows, amongst others, reviews of whether a public body acts ultra vires its prescribed powers. The doctrine of legitimate expectation essentially prescribes that in certain situations, expectations arise from the behaviour of a public body from which it would be unreasonable or unfair for it to renege and this may cover guidance. Discretion A and $\mathrm{B}$, and consequently $\mathrm{D}$, raise questions with respect to both; discretion $\mathrm{C}$ primarily raises questions with respect to illegality; however the categories are overlapping and not fixed.

\footnotetext{
${ }^{77}$ M. Fordham, Judicial Review Handbook ( ${ }^{\text {th }}$ ed Hart 2008) 2.1

${ }^{78}$ Council of Civil Service Unions v Minister for the Civil Service ("GCHQ") [1985] AC 374 per Lord Diplock.

${ }^{79}$ See GCHQ and Associated Provincial Picture Houses Ltd v Wednesbury Corporation [1948] 1 KB 223.
} 
The recent development of judicial review, and indeed administrative law, in the UK has been remarkable. Over the course of a few decades "the circumstances in which the courts have been prepared to provide relief for unlawful administrative action have expanded in spectacular fashion". ${ }^{80}$ At the same time, there have been formidable academic clashes in trying to identify the theoretical basis for judicial review. ${ }^{81}$ The particular nature of the UK's constitutional set up, including the lack of a written constitution and the overpowering strength of the Supremacy of Parliament principle, clearly contributed to this uncertainty. It is not the purpose of this paper to investigate this debate, and to speculate as to which of the three main theories is to be preferred, ${ }^{82}$ but the view espoused by the authors ${ }^{83}$ of the influential De Smith's Judicial Review is persuasive:

"In our view Parliament ought to abide by the necessary requirements of a modern European constitutional democracy (one of which is the rule of law). From that proposition follows a second: that courts ought to make the assumption that the rule of law (and other necessary requirements of constitutional democracy) are followed by the legislature. These two propositions are qualified only to the extent that the courts may submit to the authority of Parliament when it seeks clearly and unambiguously to exclude the rule of law or other constitutional fundamentals. Under what circumstances the courts are required so to submit depends upon the continuing validity of the sovereignty of Parliament as our governing constitutional principle.” 84

Under this view, therefore, the very mechanism of judicial review and the grounds upon which it can be carried out are ultimately justified by constitutional principle.

The last sentence of the citation merits attention. It recognizes the current preeminence of the doctrine of supremacy of Parliament within the UK constitutional set-up, but allows for the possibility of future change. As things stand, however, it is generally accepted that the UK Parliament may limit or extend judicial review by means of an act of Parliament, "but some 'common law theorists' are probably less willing than the 'ultra vires' adherents to accept that Parliament has absolute authority to exclude judicial review”,85

HMRC's general discretionary powers have been examined by court decisions over the years, and as we have seen in Part 2 above, these cases found that HMRC's discretionary powers allow them to enter into back duty agreements, ${ }^{86}$ to give

\footnotetext{
${ }^{80}$ Lord Woolf, J. Jowell and A Le Sueur, De Smith's Judicial Review, $6{ }^{\text {th }}$ ed., (Sweet \& Maxwell, 2009) (“De Smith”) para 1-001.

${ }^{81}$ See P. Craig, Administrative Law, 6 ${ }^{\text {th }}$ ed.,(Sweet \& Maxwell, 2008) (“Craig - Administrative Law”), chapter 1 and and De Smith, chapter 1 and references therein.

${ }^{82}$ The three theories are the ultra vires theory, the common law theory and the modified ultra vires theory.

83 The Right Hon Lord Woolf; Professor Jeffrey Jowell, QC and Professor Andrew Le Sueur.

${ }^{84}$ De Smith, para. 1-015.

${ }^{85}$ Bradley and Ewing, op. cit., at p. 727.

${ }^{86}$ IRC v Nuttall [1990] STC 194, CA.
} 
guidance and advance clearances ${ }^{87}$ and to make extra-statutory concessions in some circumstances, ${ }^{88}$ but not to enter into forward tax agreements with an individual ${ }^{89}$

In this section, the focus is on judicial review decisions on HMRC's discretionary powers, with particular reference to the creation of legitimate expectations. This provides background to the two case studies to be examined in section 5

\section{Legitimate expectations}

The protection of legitimate expectations is a basic requirement of fairness. It also stems from the rule of law, as it is conducive to predictability, regularity and certainty. Both procedural and substantive rights can be protected through the doctrine of legitimate expectations, ${ }^{90}$ however, setting out the conditions for a legitimate expectation to a substantive benefit to arise is not without difficulty. It requires a careful balance to be struck between certainty and fairness for the individual on the one hand, and flexibility and public interest on the other. ${ }^{91}$ Furthermore, one must consider the possible effects of a rigorous enforcement of legitimate expectation, which might include dampening the authorities' appetite for producing policies or other documentation which might give rise to legitimate expectations. $^{92}$

UK law, on the whole, provides considerable protection of legitimate expectations, however, the law in this area is still in a state of development. ${ }^{93}$ From the taxpayer's perspective, this ground of judicial review is of interest in that representations or assurances by HMRC can give rise to legitimate expectations. ${ }^{94}$ Since $R . v$ Inland Revenue Commissioners, ex p Preston ${ }^{95}$ courts have justified this in terms of fairness. In this case the taxpayer sought relief against the use by HMRC of their statutory powers to raise an assessment on the ground that they had given an undertaking so not to do as part of a wider agreement they reached with the taxpayer. Lord Templeman held that HMRC are not allowed to resile from such an undertaking when it would be unfair to do so. The unfairness, however, must be such as to amount to an abuse of power. ${ }^{96}$ This would take place if "their conduct would, in the case of an authority other than Crown authority, entitle the taxpayer to an injunction or damages based on breach of contract or estoppel by representation”.,"97

\footnotetext{
${ }^{87} R$ v IRC, ex p MFK Underwriting Agency Ltd [1989] STC 873, Matrix Securities v IRC [1994] STC 272, HL

${ }^{88} R$ (on the application of Wilkinson) $v$ Inland Revenue Commissioners [2006] STC 270.

${ }^{89}$ Al Fayed v Advocate General for Scotland [2004] STC 1703

${ }^{90}$ DeSmith pp. 609 et seq.

${ }^{91}$ On the arguments in favour and against the protection of substantive legitimate expectations see

Craig - Administrative Law at pp. 650-653.

92 Ibid.

${ }^{93}$ Oxfam v Her Majesty's Revenue and Customs [2009] EWHC 3078 (Ch), para. 47.

${ }^{94}$ A review of these cases can be found in Simon's Taxes (Butterworths) Binder 2 A5.303.

${ }^{95}$ [1985] 1 AC 835.

${ }^{96}$ Preston was cited in the seminal case R. v North and East Devon Health Authority Ex p. Coughlan [2001] Q.B. 213. as authority for the proposition that when a substantive legitimate expectation arose, courts would decide whether the frustration of the expectation was so unfair that to take a new and different course of action would amount to an abuse of power. For a discussion of Coughlan see Craig - Administrative Law at pp. 654-658.

${ }^{97}$ As Paul Craig has noted, "although the judgment was framed in terms of abuse of power, the Revenue's action could only have been thus regarded if its prior representation gave rise to some normative expectation which was worthy of protection” .Ibid. at p. 671.
} 
The limits of the legitimate expectation principle

Basis in a lawful promise

A particular problem in applying legitimate expectation in revenue law cases is that the orthodox position currently is that unfair, as it might seem, an ultra vires assurance cannot give rise to a legitimate expectation. ${ }^{98}$ Fairness considerations for individual taxpayers are here trumped by the public interest. It has been stated, in this respect, that allowing legitimate expectations to arise in such cases would have the "dual effect of unlawfully extending the statutory power [of the relevant public body] and destroying the ultra vires doctrine by permitting public bodies arbitrarily to extend their powers." ${ }^{99}$ Although critical of this, the courts appear to feel bound by it, subject to some softening of this position where the Human Rights Act applies to an expectation relating to property that can be a possession. ${ }^{100}$ Subject to this, the current position at law appears to be that legitimate expectation can only arise on the basis of a lawful promise or practice.

In the case of HMRC there is recognition in the case law that there is a discretion not to collect all tax due in some circumstances and this must be seen as intra vires to enable it to be protected by the doctrine of legitimate expectation. At some point, however, the failure to apply the law becomes ultra vires and therefore not subject to protection by legitmate expectation. The dividing line is illustrated in the Al Fayed case, ${ }^{101}$ where it was accepted that HMRC had power to forgo the collection of the full amount of tax due , taking into account the difficulties of assessing accurately the total amount, but no power to accept an advance assessment of liability. Thus an agreement in respect of past tax due was valid, but an agreement in respect of forward payments was ultra vires and so could not be the basis of a legitimate expectation claim. HMRC did not, therefore, act unfairly in terminating an agreement early. ${ }^{102}$ Lord Cullen was plain in finding that "[t]here can be no legitimate expectation that a public body will continue to implement an agreement when it has no power to do so."103

This gives rise to similar issues of validity to that in Wilkinson of what is a lawful concession and what is not. It involves a very difficult dividing line and one which it may be hard for a taxpayer to discern.

As Lord Justice May stated in the Rowland case, ${ }^{104}$ if the logic of the jurisprudential principle is followed through to its inexorable end (that is, ultra vires acts can never bind), this can create hardship to the individual and it is not clear why the loss should

\footnotetext{
${ }^{98} R$ (Bibi) v Newham London Borough Council [2002] 1 WLR 237, 249, para 46 per Schiemann LJ; $R$ $v$ Secretary of State for Education and Employment, Ex p Begbie [2000] 1 WLR 1115, 1125 per Gibson LJ. See the discussion and cases cited in De Smith p 636.

${ }^{99}$ R. v Ministry of Agriculture, Fisheries and Food Ex p. Hamble (Offshore) Fisheries Ltd [1995] 2 All ER 714, 731 per Sedley LJ.

${ }^{100}$ Rowland v Environment Agency [2003] EWCA Civ 1885; 2005 Ch. 1.

101 [2004] STC 1703

102 Para. 114. The court held that it was not even within HMRC's discretion to respect the then current agreement once it was understood to be ultra vires.

${ }^{103}$ See also Judge J in MFK: 'No legitimate expectation could arise from an ultra vires relaxation of the relevant statute by the body responsible for enforcing it'.

${ }^{104}$ Citing Paul Craig, Administrative Law $4^{\text {th }}$ ed 1999 pp635-650. See pp. 682-691 of the latest edition, Craig, op. cit.
} 
be borne by the person who relies on the representation. On the other hand, to allow reliance on an ultra vires statement could enable public officers to extend their powers at will, and that would be to the detriment of the public at large. There is clearly a very difficult balancing act to be performed here, no made easier by the difficulty of finding where the tightrope begins and ends.

\section{The limits of guidance}

Legitimate expectations can arise from a practice. In $R v$ IRC, ex $p$ Unilever ${ }^{105}$ it was held that HMRC could not frustrate a legitimate expectation created by its long practice of accepting a claim for a tax refund despite the statutory time limit having expired. This was so even though HMRC had not made any representation to the taxpayer about the practice claimed to be binding - it had simply developed over the years. It was not irrelevant to the judges, however that this was a procedural rather than a substantive issue.

Most of the revenue cases dealing with legitimate expectation involve representations of one of the types described in Part 2 above, either specific to the taxpayer or more general guidance. Whilst there has been some uncertainty in the past on the matter, ${ }^{106}$ in $M F K$ it was held there is "[n]o doubt [that] a statement formally published by the Revenue to the world might safely be regarded as binding, subject to its terms, in any case falling clearly within them". ${ }^{107}$ This starting point was recently confirmed in Gaines-Cooper, ${ }^{108}$ although the actual result of that case somewhat undermines the proposition, as discussed below. Circumstances might arise which justify a change in the guidance; however, HMRC accepts that it will normally remain bound to the guidance unless and until it announces a change, which would apply prospectively. ${ }^{109}$

Less formal representations by HMRC, such as a ruling or statement, may also give rise to legitimate expectations as seen in cases such as Preston. In MFK it was suggested however, that representations of this kind would require a more detailed enquiry. In particular they will only give rise to a legitimate expectation if the "taxpayer put all his cards face upwards on the table" and the ruling or statement must be "clear, unambiguous and devoid of qualification". ${ }^{110}$

This condition does not, however, seem very different from that applicable to published concessions and guidance. These more general statements are almost always subject to caveats, which frequently state that they are inoperative in cases of avoidance. How this impacts on the legitimacy of any expectations arising can be a difficult question of fact and this may be very undermining of the protection offered by the general statements and guidance as well as any individual clearances offered. Taxpayers must prove that the facts at issue fall four square with the descriptions or examples used in the guidance. This is often difficult due to the use of loose and cautious language and relatively simple examples given in the guidance.

\footnotetext{
${ }^{105} R$ v IRC, ex $p$ Unilever[1996] STC 681

${ }^{106}$ De Smith, Woolf and Jowell, “Judicial Review of Administrative Action” (5th edition) p. 938.

107 [1989] STC 873 at 892.

${ }^{108}$ Para 18. Note, however, the lack of trust by members of the tax profession to HMRC's commitment to this view. Paras. 20-21.

${ }^{109}$ Para. 19. HMRC's acceptance of this point with regards to Statements of Practice can be seen in their Administrative Law Manual ADML5100.

${ }^{110}$ At p. 892.
} 
In $R$ v Inland Revenue Comrs, ex p Fulford-Dobson ${ }^{111}$ it was held that HMRC were not bound by an extra-statutory concession because of a caveat stating that concessions would not be given "in any case where an attempt is made to use it for tax avoidance". In $R$ (on the appn of Thompson) $v$ Fletcher $^{112}$ the court cited a caveat as one of the grounds on which the taxpayers' challenge, which was based on the wording of HMRC documents, failed. Similarly, in the recently decided Hanover Company Services Limited $v$ The Commissioners for her Majesty's Revenue and Customs, ${ }^{113}$ a caveat led the First Tier Tax Tribunal to the conclusion that the representation in a particular Manual ${ }^{114}$ could not have given rise to a legitimate expectation. The particular "health warning" in this case was that found in the Introduction to HMRC's Guidance Manuals. This caveat thus applies to all HMRC Manuals and provides:

"It should not be assumed that the guidance is comprehensive nor that it will provide a definitive answer in every case. HMRC are expected to use their own judgement, based on their training and experience, in applying the guidance to the facts of particular cases...Subject to these qualifications readers may assume that the guidance given will be applied in the normal case; but where HMRC considers that there is, or may have been, avoidance of tax the guidance will not necessarily apply." 115

The decision in Hanover was one from a first level tribunal and has caused concern. It may well be appealed. If it were correct, HMRC's Manuals, as a whole, would simply be incapable of producing legitimate expectations and would be a useless tool or even worse, a trap for the unwary. It cannot be fair that HMRC can side-step completely any commitment to the interpretations laid out in its Manuals by the simple expedient of a general caveat. This is especially so once one considers the reliance placed by HMRC and some politicians on the use of guidance, as well as the recent efforts by HMRC to encourage taxpayers to comply with the interpretations contained therein. It stands to reason that guidance will not provide the definite answer in every case. Equally, the premises upon which the interpretation is given must surely be met; however, once that is done it would be unfair to the point of being an abuse of power for HMRC to be entitled to disown their interpretation on the basis of a general, exculpatory caveat. In a public law situation of this sort, it cannot be fair to apply a caveat of this sort on the basis that the party to whose detriment the caveat operates had notice of it.

The reference to "avoidance" in the caveat could be a particular source for concern. Avoidance is a vague term which means different things to different persons. The subjective nature of the term might infuse the caveat with indeterminacy, meaning that taxpayers are left with the message that the Manual will generally be followed unless it is decided that it should not.

\footnotetext{
111 [1987] STC 344 Note that this case was decided pre Wilkinson.

112 [2002] STC 1149.

113 [2010] UKFTT 256 (TC).

114 The Supply and Consideration Manual VATSC.

${ }^{115}$ Available at http://www.hmrc.gov.uk/manuals/advisory.htm. For more examples see R Fraser, "The white open spaces” - Revenue practice and penalties for negligent conduct” [2006] BTR 385, at p. 386.
} 
Reliance is another factor which can hinder the emergence of a legitimate expectation. The taxpayers' lack of reliance on the relevant Manual ${ }^{116}$ in Fletcher, for example, was another reason cited by the court in rejecting the taxpayers' challenge. Still, there appears to be some uncertainty about this factor. In Oxfam $v H M R C^{117}$ Sales J considered the issue of reliance at some length showing how its relevance varies from case to case depending on the overall context. In some contexts it can be determinative, in others less so. In a case where the assurance was only given to one taxpayer and in the court's view the public authority was not acting irrationally by adopting a different approach to that given in the assurance, the lack of detrimental reliance would be fatal. ${ }^{118}$ In other circumstances it would be irrelevant. One example given by Sales $\mathrm{J}$ is that of a general statement of policy which is not altered by the authority, but is applied differently to one particular individual without good reason. In such a case, even if the individual did not rely on the general policy, he would have a good claim to be entitled to the benefit of that policy as ordinary rules of public law prevent a public authority from acting arbitrarily and capriciously. ${ }^{119}$ On the other hand, the authors of a leading work on judicial review to conclude "it is surely right that reliance should be a 'necessary precondition' of a legitimate expectation 'where statements are made to the public at large"”. 120

A finding that a taxpayer did not rely on HMRC's published representation was determinative in Hanover. Whether a lack of reliance ought to be fatal for a taxpayer depends, as seen above, on the particular circumstances of the case and no hard and fast rule can be set. Rather disconcertingly, however, in this case the court found that the taxpayer did not rely on the guidance despite the fact that he relied on his accountant's advice who in turn had relied on the guidance. This seems to be incorrect unless there is some reason why the agent should be aware of something which makes the guidance wrong, and that view is supported by a recent first tier tribunal decision ${ }^{121}$ Ultimately, as seen, legitimate expectations are protected to ensure that authorities do not act in a manner that is so unfair as to amount to an abuse of power. Even if the need for reliance was established as a determinative factor in all cases, it would still would appear unfair to the point of an abuse of power if a taxpayer were denied protection on the ground that he relied on guidance indirectly through an advisor and

\footnotetext{
${ }^{116}$ Note that the court also found that the Manual did not support the taxpayers' case. See paras. 48 and 49. than an action for judicial review, however, similar issues were raised. An agent relied on HMRC guidance and oral advice given by HMRC's helpline in filing the tax return of a partnership on behalf of a client. The return was filed late, but within a period which guidance and advice suggested would not lead to the imposition of a penalty. The guidance and advice turned out to be misleading, and, therefore, a penalty was imposed in line with the correct interpretation of the law. The FTTT was thus asked to set the penalty aside, as empowered by section 93A(7) of the TMA on the ground of the existence of a "reasonable excuse for not delivering it [i.e. the return] in time". The question was whether having relied on what was admitted to be misleading guidance and advice constituted a 'reasonable excuse'. HMRC argued that it did not because ignorance of the law cannot be an excuse. The tribunal found that it did. For our purposes the interesting point to note is that in reaching its decision the Tribunal also found that "in this case I considered the acts of the agent - in particular the reliance on HMRC's website - as if it were reliance by the Appellant”. Para 13. Many agents do indeed rely on HMRC guidance at present- hence the concern about the Hanover case.
} 
not directly.

The value of the legitimate expectations doctrine in controlling revenue discretion The limitations discussed here explain why, despite the availability of protection for legitimate expectations arising out of formal and less formal representations, it is very seldom that taxpayers are successful in judicial review procedures on these grounds. That in itself cannot be determinative of the utility of the doctrine of legitimate expectations in keeping HMRC to their word as laid down in the various formal documentation. Beneath the admittedly thin surface of successful applications, anecdotal evidence from practitioners and professional literature suggests that in reality at most levels HMRC does generally accept the validity of a taxpayers' tax arrangements on the grounds that they conform to their stated interpretation, but there may often be discussion about the facts and HMRC will feel free to change its mind for prospective cases.

The use of legitimate expectations in the revenue field, and some particular problems raised by the jurisprudence, is considered further, in the context of two case studies, in the part that follows.

\section{Two Case Studies}

\section{A. Over-inclusive legislation narrowed by guidance: Section 16A of the Taxation of Chargeable Gains Act 1992}

The enactment of the broadly drafted section 16 A of the Taxation of Chargeable Gains Act 1992 ("s. 16A") elicited considerable dismay and even protest. The main associations of tax professionals argued that its broad scope caught objectionable and unobjectionable transactions alike, necessitating reliance on HMRC guidance and/or practice to narrow it sensibly. Other pieces of revenue legislation have been similarly charged, turning the issue into one of more general concern. ${ }^{122}$

\section{Background}

S. 16A contains a Targeted Anti-Avoidance Rule ("TAAR") which is meant to target the objectionable creation and use of capital losses. The history of the enactment of this provision is instructive and deserves being laid out in some detail. The PreBudget Report $2006^{123}$ included a draft of a more comprehensive TAAR than that then in force in this area. ${ }^{124} \mathrm{~A}$ statement setting out the principles underlying the

\footnotetext{
${ }^{122}$ Another example is the Stamp Duty Land Tax TAAR introduced by s 75 A of the Finance Act 2003. See Patrick Cannon, "New SDLT general anti-avoidance rule" Tax Journal 2007, 874, 6-8. Similar concerns were raised as early as 1995: Amanda K Rowland, "Is the Revenue being fair? Revenue Statements and judicial review” BTR 2 [1995] 115-121.Arguably, a similar issue has arisen in recent years in other areas of law, such as the Sexual Offences Act 2003 and the Bribery Act 2010. On the Sexual Offences Act 2003 see J. R. Spencer, "The Sexual Offences Act 2003: (2) Child and family offences”, Criminal Law Review [2004] 347.

${ }^{123}$ This was published on the $6^{\text {th }}$ of December 2006.

${ }^{124}$ A narrower version of this TAAR, aimed only at the creation and use of capital losses by companies, was first introduced in the Finance Act 2006 following a brief period of consultation and found its way in section 8 (2A) to (2C) of the Taxation of Chargeable Gains Act 1992. http://webarchive.nationalarchives.gov.uk/20091222074811/http://www.hmrc.gov.uk/pbr2005/capital-
} 
TAAR (the "Statement”) and draft guidance were published at the same time. ${ }^{125}$ Apart from providing a description of the type of transactions the TAAR was targeting, the guidance also included examples of transactions that HMRC deemed to be within or outside the ambit of the TAAR. These publications marked the start of a consultation which saw a number of bodies express their concerns, ${ }^{126}$ despite being in agreement with the broad policy behind the TAAR. The Chartered Institute of Taxation ("CIOT") ${ }^{127}$ and the Tax Faculty of the Institute of Chartered Accountants in England and Wales ("ICAEW") ${ }^{128}$ both presented hard-hitting documents. Their concern was primarily that the TAAR appeared to catch a broader range of transactions than HMRC envisaged in the guidance and Statement. A number of issues followed from this primary concern. Firstly, that relying on HMRC discretion not to apply the full force of the TAAR was not acceptable. Secondly, that HMRC might not have the discretion to apply the TAAR in this restrictive manner.

These concerns reached, and were discussed by the House of Commons Public Bill Committee. ${ }^{129}$ The response of Ed Balls, then Economic Secretary to the Treasury, echoed the written response given by HMRC. HMRC concluded: ${ }^{130}$

The Government believes that the rule will not be applicable in the extremely wide range of situations asserted by the respondents... Where there have been no contrived or artificial arrangements, or where there has been a genuine loss on a genuine disposal, the rule will not apply. The Government believes therefore that most of the concerns raised during the consultation are unfounded and the position can be clarified through guidance.

HMRC thus issued two revised and extended versions of the guidance, ${ }^{131}$ containing some significant changes to the explanatory part and a considerable number of new examples and more detailed explanations as to why HMRC believed some were caught and others were not. Crucially, however, the draft legislation was unchanged

losses.pdf. The draft guidance was subject to a period of consultation lasting till the $5^{\text {th }}$ of February 2006. A revised draft of the legislation was published on the $22^{\text {nd }}$ March 2006 and was then included in Finance Bill 2006. Revised Guidance was also published on the 22 March 2006.

http://www.hmrc.gov.uk/budget2006/capital-losses.pdf

${ }^{125}$ http://customs.hmrc.gov.uk/channelsPortalWebApp/channelsPortalWebApp.portal?_nfpb=true\&_pa

geLabel=pageImport_ShowContent\&id=HMCE_PROD1_026426\&propertyType=document

${ }^{126}$ Both in writing as well as during purposely convened meetings. The TAAR was discussed with a number of representative bodies at a meeting of the CGT Review Group on 16 January 2007. This was followed up at a separate meeting with representatives of the CIOT, Law Society, STEP and the Tax Faculty of the ICAEW on 6 February 2007.

${ }^{127}$ The CIOT presented its views, as well as those of the Law Society and the Society of Trust and Estate Practitioners. http://www.tax.org.uk/attach.pl/5250/5456/CGTlossesTAAR\%20final090207.pdf ${ }^{128}$ TAXREP 07/07. This document can be found at:

http://www.icaew.com/index.cfm/route/157009/icaew_ga/en/Faculties/Tax/Publications_and_technical _guidance/Publications_archive/Tax_representations_2007

${ }^{129}$ The relevant debates took place on Thursday the $17^{\text {th }}$ of May 2007 and can be found at: http://www.publications.parliament.uk/pa/cm200607/cmpublic/finance/070517/am/70517s01.htm http://www.publications.parliament.uk/pa/cm200607/cmpublic/finance/070517/pm/70517s01.htm

${ }^{130}$ http://customs.hmrc.gov.uk/channelsPortalWebApp/channelsPortalWebApp.portal?_nfpb=true\&_pa geLabel=pageLibrary_ConsultationDocuments\&propertyType=document\&columns=1\&id=HMCE_P ROD1_027247

${ }^{131}$ These were issued on the $1^{\text {st }}$ of March and then again on the $19^{\text {th }}$ of July 2007 http://www.hmrc.gov.uk/cgt/cgt-recent-developments.pdf 
and it was thus introduced in section 27 of Finance Act 2007. ${ }^{132}$ The CIOT responded to both revisions of Guidance, ${ }^{133}$ reiterating its broader concerns in no uncertain terms:"[t]he CIOT disagrees strongly with the majority of HMRC's Guidance, believing it to be in contradiction to the clear wording of section 16." ${ }^{134}$ It also stated that whilst it agreed with some of the conclusions on the applicability of the TAAR to the examples given, it disagreed with the reasoning in all but one example.

\section{Main charge: law broader than guidance}

S. 16 A reads:

"(1) For the purposes of this Act, "allowable loss" does not include a loss accruing to a person if-

(a) it accrues to the person directly or indirectly in consequence of, or otherwise in connection with, any arrangements, and

(b) the main purpose, or one of the main purposes, of the arrangements is to secure a tax advantage.

(2) For the purposes of subsection (1)-

"arrangements" includes any agreement, understanding, scheme, transaction or series of transactions (whether or not legally enforceable), and

"tax advantage" means-

(a) relief or increased relief from tax,

(b) repayment or increased repayment of tax,

(c) the avoidance or reduction of a charge to tax or an assessment to tax, or

(d) the avoidance of a possible assessment to tax,

and for the purposes of this definition "tax" means capital gains tax, corporation tax or income tax.

(3) For the purposes of subsection (1) it does not matter-

(a) whether the loss accrues at a time when there are no chargeable gains from which it could otherwise have been deducted, or

(b) whether the tax advantage is secured for the person to whom the loss accrues or for any other person.”

The representative bodies' main concern is that HMRC's interpretation, as it emerges

\footnotetext{
${ }^{132}$ The section had effect in relation to losses accruing on disposals made on or after 6th December 2006.

${ }^{133}$ These are available at http://www.tax.org.uk/

${ }^{134}$ Ibid. para. 2.1.
} 
from the Guidance, ${ }^{135}$ appears to narrow s. $16 \mathrm{~A}$ by appealing to tests that are not found in the provision itself. The Guidance includes, for example, ${ }^{136}$ the following two statements: "[t]he straightforward use of a statutory relief does not of itself bring arrangements within the TAAR" 137 and that "[t]he legislation will not apply where there is a genuine economic transaction that gives rise to a real economic loss as a result of a real disposal". ${ }^{138}$ These statements are not as clearly off the mark as others found in previous versions of the Guidance, ${ }^{139}$ nevertheless, they are still, arguably, misleading and incorrect.

Take the simple example of an individual who holds shares at a loss and decides to sell them. Assume also that the sole purpose of the sale, made to an independent third party, is that of crystallizing the loss to be set against a chargeable gain made that year. Had the individual not made the gain he would have held on to the shares in the hope that they might eventually regain their value. Both statements from the Guidance suggest that such a sale is not caught by the TAAR; however one might argue that this view is not supported by the TAAR's wording. The sale constitutes an arrangement which was certainly carried out for the sole purpose of obtaining tax relief. The requirements of the legislation appear to be met. That the sale was a "straightforward use of a statutory relief" or that it was a "genuine economic transaction that gives rise to a real economic loss as a result of a real disposal" arguably make no difference to the application of the TAAR in this case.

The examples provided in the Guidance and the explanatory notes ${ }^{140}$ reveal that HMRC's interpretation relies on tests and criteria not found in the legislation. We can take one of the examples as an illustration.

"An individual, J, invests in shares under the Enterprise Investment Scheme (EIS), with a view to securing income tax relief. In order to fund the purchase of the shares $\mathrm{J}$ sells a capital asset which is standing at a loss to a third party."

After agreeing that the transactions would constitute an arrangement for the purposes of the TAAR, HMRC state:

"To decide what J's main purpose was in entering into these arrangements, it is necessary to consider the overall economic objective of the arrangements, and whether that objective is being fulfilled in a straightforward way, or whether additional, complex or costly steps have been inserted. J has made a real disposal of a capital asset in a straightforward way, and has incurred a genuine economic loss. There have been

\footnotetext{
${ }^{135}$ Unless the context suggest otherwise, "Guidance” from this point on refers to the guidance issued on the $19^{\text {th }}$ of July 2007.

${ }^{136}$ More detailed analysis of the Guidance can be found in the CIOT documents cited above and in S. McKie “Should Humpty Dumpty be your guide?” (2007) 6 Private Client Business 416-426; E. Reed “Br'er Gordon and TAAR Baby” (2007) 5 Private Client Business 323-330; J. De Souza, “Tax Editor’s Notes”, (2007) Conveyancer and Property Lawyer 386-390.

${ }^{137}$ Para. 13.

138 Para. 20.

139 The draft Guidance issued on the $6^{\text {th }}$ of December 2006 included, for example, the statement: "[t]he legislation is intended to have effect where a person enters deliberately and knowingly into arrangements to avoid tax", whilst the legislation does not speak of avoidance or of specific intentions.

${ }^{140}$ Explanatory notes to UK legislation have no interpretative force. In most circumstances the Courts will look only at the wording of the legislation when construing it- background documents are generally considered irrelevant- see fn 143 below and text thereto..
} 
no additional, costly or complex steps inserted into the transactions. The fact that the disposal has been made with a view to using the proceeds to invest in shares which fall within the EIS tax regime does not mean that the arrangements have been entered into with a main purpose of securing a tax advantage, because the straightforward use of a statutory relief does not of itself bring arrangements within the TAAR. Hence the TAAR does not apply.”

The CIOT have argued that it is hard to understand why this transaction is not caught by the TAAR as currently worded. There clearly is an arrangement the main purpose of which is to obtain tax relief. It is true, as HMRC note, that J's objective is being fulfilled in a straightforward way, that no additional, complex or costly steps have been inserted, and that $\mathrm{J}$ has made a real disposal and has incurred a genuine economic loss. It not fully clear, however, why these facts ought to bring J outside the scope of the TAAR. The language of the provision does not suggest that they should.

These facts, or tests, are used by HMRC in determining the applicability of the TAAR to many of the examples in the Guidance. They are also listed as circumstances that need to be taken into consideration to determine if one of the main purposes of the arrangement was that of obtaining a tax advantage. Whilst they may seem to be intuitive tests of tax avoidance, they are not derived from the language of the legislation, and it is beyond the power of HMRC to substitute its own understanding of the text for the meaning of the wording, ultimately as interpreted by the Courts. The fact that HMRC may have been involved in designing the policy of the legislation and instructing the draftsman does not mean that they have any role in interpretation under the UK system and to assert that they do would be beyond their powers. Here it seems that HMRC are interpreting the TAAR by giving effect to what they envisaged its underlying principle to be rather than its wording. In effect they are tying to use this as a widely based anti-avoidance provision rather than relating to its precise terms.

Although the discrepancy between the Guidance and the TAAR was forcefully brought to the attention of HMRC and Government by the representative bodies, the response of the Government appeared to be that guidance was adequate to cut down the legislation and make it clear that the rule will not apply where there have been no contrived or artificial arrangements, or where there has been a genuine loss on a genuine disposal. This response is significant. At no stage did HMRC or the Economic Secretary to the Treasury addressing the point during the Parliamentary debates address the fact that these factors could not be inferred from the language of the TAAR. They simply repeated that the TAAR was not as broad as suggested, without paying heed to the simple matter that it was hard to see the grounds on which it could be narrowed in the way suggested.

During the Parliamentary debates the Economic Secretary, the Rt. Hon Ed Balls said:

"In the real world of tax policy making and, with respect to the hon. Member for Braintree, in the real world of business, the best way to provide clarity is not always to make legislation more complex or restrictive. Indeed, adding such complexity can undermine the best efforts of both sides to find a sensible way forward. That is why consultation on guidance, rather than restriction and legislation, can often be a better was to proceed in tax policy making. I urge him to reflect on that point a little further.” 
Rather than making sure that the wording of the legislation reflects the intended principle, the approach was to insist that the wording should be understood in line with the principle.

\section{Discussion}

Statutory interpretation is not a precise science. For a start its method changes over time. Indeed, it is often said that in the UK there have been shifts from the mischief rule to the literal rule, onto the golden rule and finally to the purposive approach. Furthermore, there was never a clean cut from one to the other and examples can be found within each period of the different approaches. ${ }^{141}$ All one can discern therefore, is a general trend within a given period. ${ }^{142}$ Also, judges' application of these rules inevitably differs.

Purposive interpretation is currently the dominant mode of interpretation in the UK. ${ }^{143}$ It enjoins a court to interpret a statute in a manner that furthers its purpose even if that necessitates a strained interpretation of the language. Resort to the purpose of the statute is not, as is at times opined, limited only to situations in which an ordinary interpretation of the statute would lead to an absurdity or an injustice. Indeed, the purpose of a statute is part of the context against which the words in the statute must be read. The purpose of the provision or the statute may be sought by looking within the four corners of the statute, as well as at external sources such as earlier statutes, relevant international treaties, government reports, and now, following Pepper v. Hart, ${ }^{144}$ subject to the limitations mentioned therein, Parliamentary debates. ${ }^{145}$

Whilst statutory purpose thus plays an important role in the current practice of interpretation, and the set of materials which may be consulted is wider than ever, the starting point in statutory interpretation remains the language of the statute. Furthermore, whilst a strained meaning can be given to the language of a statute so as to give effect to its purpose, there is a point beyond which interpretation becomes unacceptable legislation. The difficulty is that in practice individual judges will identify this point at different parts of the interpretation-legislation continuum. In other words, individual judges have different appetites for giving statues strained meanings.

Examples of rather strained interpretations can be found in the tax field, including in

\footnotetext{
${ }^{141}$ See Zander's comments to the effect that although there was a general move towards a purposive approach in the latter part of the twentieth century "there were still plenty of examples of the literal approach” M. Zander, The Law-Making Process, $6^{\text {th }}$ ed., (Cambridge University Press, 2004) p. 146. ${ }_{142}$ The Law Commission, The Interpretation of Statutes, Law Com. No. 21, (HMSO) (1969), para. [22].

143 Carter v. Bradbeer [1975] 3 All E.R. 158, 161 g per Lord Diplock; Pepper v. Hart [1993] A.C. 593, 617 E per Lord Griffiths; Regina (Quintavalle) v. Secretary of State for Health [2003] UKHL 13, [2003] 2 A.C. 687, at [21] per Lord Steyn. See also J. Steyn, 'The Intractable Problem of the Interpretation of Legal Texts in S. Worthington (ed.) Commercial Law and Commercial Practice (Hart Publishing) (2003) pp.7, 12 and 16.

144 [1992] S.T.C. 898.

${ }^{145}$ See J. Bell and G. Engle, Cross: Statutory Interpretation, $3^{\text {rd }}$ ed., (Butterworths, 1995), chapters 5 and 6; and, Zander op. cit. at pp. 149-179. Pepper v. Hart has been criticised in some quarters. See for example: J. Steyn, 'Pepper v. Hart; A Re-examination' (2001) OJLS, 21, 59; A. Kavanagh, 'Pepper v Hart and Matters of Constitutional Principle’ (2005) LQR, 121, 98.
} 
the Ramsay line of cases on tax avoidance. ${ }^{146}$ Indeed, once it became clear that the Ramsay Approach could, for constitutional reasons, only be a process of interpretation, one was forced to conclude that either some of the cases following that approach were either decided wrongly or involved a considerably strained interpretation. ${ }^{147}$ On the other hand, tax cases can be found in which judges acknowledged the need to refer to the purpose of the statute but felt unable to stretch the language of the legislation beyond a certain limit to give effect to such purpose.

Having briefly discussed purposive interpretation we can now assess the value of HMRC's section 16 A Guidance. The CIOT believe that much of the s16 A Guidance "represents concessionary treatment which may well be beyond the power of HMRC to promulgate" ${ }^{148}$ It may appear strange for a body representing taxpayers to make this point, because HMRC may well be taking a more lenient view of the law than the CIOT. The danger lies in the extent to which taxpayers (and their advisers) can rely on this Guidance if HMRC change their minds. For a professional body this is of the utmost importance in advising its members.

It might be argued, on HMRC's behalf, that their interpretation of s. $16 \mathrm{~A}$ is simply strongly purposive and that this is well within their powers of management. Therefore, under the principles discussed in part 4 above, the Guidance would be such as to found a legitimate expectation. The lack of clarity about the exact limits of purposive interpretation favours HMRC in this regard in that strong purposivism is one of the different, yet apparently equally possible, forms of purposive interpretation espoused by UK courts over the past few decades. This view could be upheld by the courts, but it could also be argued that HMRC are going beyond strong purposivism in this instance because they give little attention to the words used in the provision. Indeed, some might say that rather than employing the purpose of the provision to inform its interpretation, HMRC appear to substitute the provision with different formulations of the purpose and apply the latter to test whether the transaction is caught. Even strong purposivism does not allow for the simple substitution of the words of the statute with the purported purpose.

The problem for the taxpayer at present is that he cannot know whether this is an interpretation within the scope of HMRC's powers on the one hand or a concession which attempts to legislate where Parliament has not done so (as suggested might occur by the House of Lords in Wilkinson) or promises to refrain from collecting tax due (as was held to be ultra vires in Al Fayed,) on the other hand. The section $16 \mathrm{~A}$ Guidance differs from Al Fayed in that it is guidance to all and not a deal with one taxpayer- nevertheless it may be held by the courts to favour some taxpayers over others. If the taxpayer cannot be sure whether the Guidance is within the lawful power of HMRC to give then he cannot know whether the Guidance will give rise to a legitimate expectation and so cannot rely on it.

These are not purely academic concerns. Clearly they preoccupied the ICAEW ${ }^{149}$ and the CIOT. If, as is now being discussed, a General Anti Avoidance Rule is to be

\footnotetext{
${ }^{146}$ WT Ramsay Ltd v IRC [1981] STC 174.

${ }^{147}$ For a discussion of interpretation of tax statutes in this context see J Freedman, 'Interpreting Tax Statutes: Tax Avoidance and the Intention of Parliament' (2007) 123 Law Quarterly Review 53.

${ }^{148}$ Para 5,2 CIOT note "Targeted Anti-avoidance Rule guidance" $14^{\text {th }}$ Jan 2008 .

${ }^{149}$ Para 36 ICAEW note, supra. .
} 
introduced in the UK, this will almost certainly be accompanied by guidance and even without this, guidance is being given a greater and greater role in the tax system. These, then, are issues that need to be clarified as a matter of some urgency. There should at least be an undertaking by HMRC, backed by Government, that guidance will not be retracted without a certain period of notice and never retrospectively. The protection of legitimate expectations is ultimately based on fairness, surely, nothing could be more unfair than HMRC arguing that they ought not to be bound by its interpretation because it acted ultra vires in giving it. This would be particularly so given the vociferous opposition to the guidance during the consultation, and HMRC and the then Government's insistence on proceeding with it.

\section{B. The IR 20 Guidance cases- Davies and Gaines-Cooper.}

The second case study involves recent litigation which is to be heard by the Supreme Court. The case is worthy of a topic for a paper in its own right ${ }^{150}$; the discussion in this paper will be brief but is important, because these joined cases bring together questions about the reliability or otherwise of HMRC Guidance and, potentially, the extent to which concessions may become binding by way of practice as well as written guidance. In fact, the Court of Appeal avoided many of these issues in the case before them ( $R$ (on the application of Davies and another) $v H M R C ; R$ (on the application of Gaines-Cooper) v HMRC (hereafter the Gaines-Cooper case) ${ }^{151}$ The judgments are generally considered to be rather disappointing by the tax community because of their failure to settle some of these points and there is considerable relief when the Supreme Court agreed to hear the appeal. On the other hand, the case does confirm the principle that extra-statutory guidance may be binding and that HMRC cannot simply claim in every case that the Wilkinson principle prevents them from making any binding concessions at all.

IR 20

IR 20 was the name given to guidance on the definition of residence and ordinary residence for tax purposes, both of which concepts have tax implications. ${ }^{152}$ Its history is given in the case. The definition of residence is derived from case law only and as long ago as 1936 the Income Tax Codification Committee complained about the absence of guidance to taxpayers. In 1973 the Inland Revenue as it then was issued a booklet - IR 20 - to give guidance. This is an excellent example of an indeterminate area of law. It is unlikely that a statutory bright line definition could ever be devised that would not be open to significant manipulation and therefore it seems to be an appropriate area for a broad statutory provision backed up by guidance. It had widely been thought by practitioners and commentators that IR20 did provide some bright lines or safe harbours but the Court of Appeal held in the Gaines Cooper case held that on a proper interpretation of the Guidance the specific paragraphs relied upon had to be read in the context of the legislation as a whole and, as such, did not have the interpretation the taxpayers argued for. In addition the Court did not consider that the HMRC had changed its interpretation and application (despite considerable evidence to the contrary).

\footnotetext{
${ }^{150}$ For case comments see S. Eden, [2010] BTR 322; L. Higginbottom and A. Savin, "Gaines-Cooper: case review”, 2010 Tax Journal 1019, 7-8; P. Vaines and B.Wilkins, “Gaines-Cooper”, 2010 Tax Journal 1019, 9.

151 [2010] 860

152 This has been withdrawn but is, unusually, available online at http://www.hmrc.gov.uk/pdfs/ir20.pdf
} 
The preface of IR20 states

"The notes below are not binding in law and do not affect rights of appeal about your own tax..... You should bear in mind that the booklet offers general guidance on how the rules apply, but whether the guidance is appropriate in a particular case will depend on all the facts of that case. If you have any difficulty in applying the rules in your own case, you should consult an HM Revenue \& Customs Tax Office.....

Some practices explained in this booklet are concessions made by HM Revenue \& Customs.

\section{A concession will not be given in any case where an attempt is made to use it for tax avoidance.”}

As will be apparent from the discussion of judicial review in part 4, this raises many issues about the reliability of IR20, to which we may add the point that since this area of the law is so fact dependent, each case depends entirely on its own particular details. Further paragraphs of the Guidance are also very broad and therefore it is not really surprising that the Court of Appeal found a way to uphold HMRC's interpretation of the Guidance on all the facts. It is a little more surprising, however, that the Court went into great detail on the wording of the paragraphs of the Guidance as if they were legislation. It was strange to see Guidance given this kind of scrutiny, since it is clearly not written as legislation, and even stranger in a judicial review case, which one might have expected to focus rather more on the question of what might fairly have been expected from past practice as well as the guidance, rather than a detailed scrutiny of the precise wording.

What is more, IR20 has now been replaced by HMRC $6{ }^{153}$ which seems to be written in terms that make even more effort than IR20 to avoid being binding. It is not clear that these efforts to prevent guidance from being something the taxpayer can rely on are conducive to the relationship of trust that HMRC is tying to create with taxpayers and the Court of Appeal in Gaines-Cooper seem to think is important for the purposes of tax administration.

\section{The decision in Gaines-Cooper}

The Court of Appeal considered two different paragraphs of IR20. In one aprt of its decision it decided that leaving the UK permanently or indefinitely could not be achieved simply by satisfying the bright line tests in paragraphs 2.7 to 2.9 of the Guidance involving absences for specified lengths of time as follows:

"2.7 If you go abroad permanently, you will be treated as remaining resident and ordinarily resident if your visits to the UK average 91 days or more a year ....

2.8 If you claim that you are no longer resident and ordinarily resident, we may ask you to give some evidence that you have left the UK permanently, or to live outside the UK for three

${ }^{153}$ Available at http://www.hmrc.gov.uk/cnr/hmrc6.pdf 
years or more. This evidence might be, for example, that you have taken steps to acquire accommodation abroad to live in as a permanent home, and if you continue to have property in the UK for your use, the reason is consistent with your stated aim of living abroad permanently or for three years or more. If you have left the UK permanently or for at least three years, you will be treated as resident and not ordinarily resident from the day after the date of your departure providing:

a) Your absence from the UK has covered at least a whole tax year, and;

b) Your visits to the UK since leaving:

- have totalled less than 183 days in any tax year and;

- have averaged less than 91 days a tax year.

2.9 If you do not have this evidence, but you have gone abroad for a settled purpose (this would include a fixed object or intention in which you are going to be engaged for an extended period of time), you will be treated as not resident and not ordinarily resident from the day after the date of your departure providing:

a) Your absence from the UK has covered at least a whole tax year and;

b) Your visits to the UK since leaving:

- have totalled less than 183 days in any tax year and;

- have averaged less than 91 days a tax year ...

c) Your absence actually covers three years from your departure, or;

d) Evidence becomes available to show that you have left the UK permanently;

e) Providing in either case your visits to the UK since leaving have totalled less than 183 days in any tax year and have averaged less than 91 days a tax year.”

Moses LJ explained that the dispute focused on whether, under these paragraphs, it was necessary for a taxpayer to demonstrate he had severed his ties to the extent that his previous social and family ties in the United Kingdom were no longer retained. The taxpayers argued that this did not arise on a proper construction of these paragraphs, and even if it did, this was not a construction applied by the Revenue until these cases provoked an unannounced change of policy. The Court held that because these paragraphs were headed "Leaving the UK permanently or 
indefinitely" and in the light of the case law, it was necessary to demonstrate a distinct break from former social and family ties within the UK. One leading tax QC has described this interpretation of the Guidance as bizarre ${ }^{154}$ and it did surprise many. It could be supported by reference to the case law, but it is hard to see that it was apparent from the Guidance that this was a qualification of the tests as stated there. Nevertheless their Lordships held that the taxpayers fell outwith the circumstances which, would have gained them non-resident status under IR 20. Further they considered that there had not altered its interpretation but merely engaged in closer and more rigorous scrutiny and policing of the growing number of claims. ${ }^{155}$.

Thus this decision did not deal head on with the argument that HMRC's Guidance had involved an ultra vires concession, because they did not interpret it to have contained any concession at all. Instead the Court of Appeal read into the Guidance the qualifications to make it consistent with the case law as HMRC now see it and as the Court agrees it should be read without the need for concession. This might be seen as an ingenious way of dealing with the problem, but it gives taxpayers very few signposts about the real value of HMRC Guidance despite the lip service to the possibility of it being binding on HMRC. It has been taken as giving some comfort to taxpayers that Moses LJ stated that “ the guidance in IR20 was plainly within the revenue's powers of providing statements of practice and identifying how it proposed to deal with the residential status of taxpayers in particular circumstances” but given that he considered that IR20 was merely intended to re-state the law this does not give any indication of how far he would feel such guidance could go beyond he law, if at all. Moses LJ does cite Blake $\mathrm{J}$ in $R$ (on the application of Lower Mill Estate Ltd and Conservation Builders) v HMRC ${ }^{156}$ who stated that

"the whole doctrine of legitimate expectation is of benefit, and only real value, where, on a true understanding of the facts and the law, the taxpayer is, or may well be, liable to tax. Despite that, however, it would be oppressive or unjust . . . to require him ... to pay the tax because the conduct of the tax authorities, in the exercise of their management powers, has legitimately created the belief that tax would not be payable for a particular period, for a particular reason”.

This was dealt with, however, as part of the debate about an important procedural issue, not discussed further here, relating to the stage at which a judicial review application can be made. The contradiction of stating that HMRC must levy tax due and that they may also apply their own interpretation of the law in indeterminate cases such as this, where that interpretation may prove to be incorrect, or even deviate deliberately from the strict law in some cases, was left hanging in the air.

\footnotetext{
154 James Kessler QC. Taxation of Foreign Domiciliaries draft of the 9th edition forthcoming September 2010- lectures based on book available at http://www.kessler.co.uk/lectures/Residence_of_Individuals_lecture.pdf

${ }^{155}$ Ward LJ at para 121.

156 2009] EWHC 2409
} 
It remains to be seen whether the Supreme Court will also deal with this case without facing the most difficult issues head on. The case as it stands now certainly does illustrate the dangers of relying on the wording of HMRC guidance too literally and supports the concerns of the professional bodies about the Guidance on section16A.

\section{CONCLUSION AND PROPOSALS FOR REFORM}

Vesting a revenue authority with sufficient discretion to enable it to operate efficiently, whilst ensuring that there are processes in place to keep it in check, is not without difficulty. This balancing act takes place against the background of a more general constitutional and administrative law reality, adding a distinctive national flavour. In the third part of this paper we outlined the unique features of the UK constitution that form the background to the way in which the discretion of HMRC is assessed and controlled.

The fourth and fifth part of this paper focused on a limited, yet crucial, set of discretions vested in the UK revenue authority that lie at the border of what may be termed quasi-legislative and quasi-judicial functions. Two case studies were considered, revealing a distinctive uncertainty over these discretions currently concerning the UK tax community, particularly regarding the use of non-statutory guidance of different types. As the role of such guidance appears to be increasing in the UK system, the case for addressing some of these causes of uncertainty strengthens.

The first area of concern regards the boundary of permissible interpretation. As seen, there is inevitably some uncertainty as to whether HMRC's interpretations have strayed into the legislative or the concessionary area, given the indeterminacy of much tax law. There is therefore some lack of clarity as to which concessions and waivers are intra vires (that is within HMRC's powers of management) and which are not under the Wilkinson principle.

This is important because if guidance is found to be even partially concessionary or based on an incorrect view of the law, then questions arise on the extent to which taxpayers can rely on it in ordering their tax affairs. There is a clash here between the concept of illegality, which prevents HMRC from acting ultra vires, and judicial review based on legitimate expectations The driving concept in the latter area should be fairness, which leads to the basic premise that taxpayers ought to be able to rely on HMRC's expressed interpretation of a statute of legislation, even if that involves some concessionary elements, for how are taxpayers to know whether these elements are ultra vires or not? As shown above, however, an expectation can only be legitimate if it is founded on a lawful act or interpretation. This is logical but raises real issues of the extent to which judicial review can achieve fairness for the individual. Criticisms of this principle from the courts and commentators suggests that the principle may be softened, but this involves a modification of the law of judicial review. 
Uncertainties currently also surrounds the extent to which HMRC can shuffle off the constraints of guidance by the simple expedient of a general caveat, in which case it is substantially devalued for many ordinary taxpayers of the kind for whom it is intended to increase and not create lack of clarity. Further there is a difficult line between the increase of policing and enforcement and a change in interpretation. The extent to which a taxpayer need have relied or indeed suffered a detriment by relying on the guidance is also a grey area in judicial review proceedings.

No easy solution lies for some of these issues and, where they are bound up with the development of the law of judicial review more generally they may take some time to be decided and they may be determined in non-revenue law cases, which could give rise to rather different considerations. One way forward would be for all concessions and guidance to have a statutory basis. Indeed, many concessions are now in the process of being enacted following Wilkinson. Clearly it is preferable to deal with issues through properly drafted legislation wherever possible, but this counsel of perfection does not allow for the realities of a complex system that needs some administrative discretion if it is not to seize up altogether.

Where guidance is concerned, some might prefer precise and detailed drafting but this has shown itself to be inadequate and to create opportunities for avoidance by encouraging creative compliance. Guidance therefore has a role to play along side legislation founded on principles, but if it is to be used taxpayers must know what its effect is to be. Judicial review raises procedural difficulties and is time consuming and expensive. It has been suggested that a specific statutory right of action on grounds of unfairness should be created to be available against the HMRC in connection with extra-statutory guidance. ${ }^{157}$ This might be worth exploring, although it would no doubt encounter many of the same issues as have been discussed here. Improving the judicial review procedure and clarifying its application would obviously be valuable and it is to be hoped that the Supreme Court will seize the opportunity in the Gaines -Cooper case since direction is badly needed.

Some improvements could be made by means of a few relatively simple steps. For a start, there should be a clear scheme of documentation in which HMRC lays out its interpretations and guidance. Currently they are to be found in various forms and locations as described in Part 2 above. The documentation should be easy to find and download, and it is imperative that this extends to past versions too. Currently practice statements and manuals can change overnight and without any trace of the previous version. ${ }^{158}$ Blanket caveats ought not to be employed or allowed. Stating that guidance does not apply if there is perceived tax avoidance essentially translates into HMRC being at liberty to decide whether to follow their guidance or not, thus negating the guidance of any utility. Finally, HMRC ought to be clear on the face of the document whether it considers the contents of guidance to be interpretative or concessionary. Further, any changes to guidance and its implementation should take effect only after a certain time period and with proper notice. These requirements

\footnotetext{
${ }^{157}$ A. Rowland, "Is the Revenue Being Fair? Revenue Statements and Judicial Review”, 1995 BTR 115. This was written a long time before some of the recent developments in the law of judicial review. ${ }^{158}$ In one case, $R$ (on the appn of Thompson) v Fletcher [2002] STC 1149, the Tribunal noted that the parties could not reconstitute the guidance for the time the transaction took place as a result of this.
} 
could be spelt out in the HMRC Charter ${ }^{159}$ and this might give this document some of the teeth it currently lacks.

Whilst better drafting of legislation which would reduce the need for guidance and concessions should not be abandoned as an aim, precision in tax law is unattainable in the real world. These modest proposals would not solve all the difficult questions raised, but they would constitute a small step in the right direction

159 See fn 3 above. 


\section{Oxford University Centre for Business \\ TAXATION \\ Working PAPER SERIES}

WP10/21 de la Feria, Rita Reverberation of Legal Principles: Further Thoughts on the Development of an EU Principle of Prohibition of Abuse of Law

WP10/20 Haufler, Andreas and Frank Stähler Tax competition in a simple model with heterogeneous firms: How larger markets reduce profit taxes

WP10/19 Cnossen, Sijbren Improving the VAT Treatment of Exempt Immovable Property in the European Union

WP10/18 Grubert, Harry and Richard Krever VAT and Financial Supplies: What should be taxed?

WP10/17 Gendron, Pierre-Pascal, VAT Treatment of Public Sector Bodies: The Canadian Model

WP10/16 Niepmann, Friederike and Tim Schmidt-Eisenlohr, Bank Bailouts, International Linkages and Cooperation

WP10/15 Bond, Stephen and Jing Xing, Corporate taxation and capital accumulation

WP10/14 Lockwood, Ben, How should financial intermediation services be taxed?

WP10/13 Becker, Johannes, Fuest, Clemens and Nadine Riedel, Corporate tax effects on the quality and quantity of FDI

WP10/12 Fuest, Clemens and Nadine Riedel, Tax Evasion and Tax Avoidance in Developing Countries: The Role of International Profit Shifting

WP10/11 Wildasin, David E., State Corporation Income Taxation: An Economic Perspective on Nexus

WP10/10 Becker, Johannes and Marco Runkel, Corporate tax regime and international allocation of ownership

WP10/09 Simpson, Helen, How do firms' outward FDI strategies relate to their activity at home? Empirical evidence for the UK

WP10/08 Voget, Johannes, Headquarter Relocations and International Taxation 
WP10/07 Devereux, Michael P. and Simon Loretz, Evaluating Neutrality Properties of Corporate Tax Reforms

WP10/06 Davies, Ronald B. and Lourenço S. Paz, Tariffs Versus VAT in the Presence of Heterogeneous Firms and an Informal Sector

WP10/05 Finke, Katharina, Heckemeyer, Jost H., Reister Timo and Christoph Spengel, Impact of Tax Rate Cut Cum Base Broadening Reforms on Heterogeneous Firms - Learning from the German Tax Reform 2008

WP10/04 Koh, Hyun-Ju and Nadine Riedel, Do Governments Tax Agglomeration Rents?

WP10/03 Dischinger, Matthias and Nadine Riedel, The Role of Headquarters in Multinational Profit Shifting Strategies

WP10/02 Vrijburg, Hendrik and Ruud A. de Mooij, Enhanced Cooperation in an asymmetric model of Tax Competition

WP10/01 Bettendorf, Leon, van der Horst, Albert, de Mooij, Ruud A. and Hendrik Vrijburg, Corporate tax consolidation and enhanced cooperation in the European Union

WP09/32 Bettendorf, Leon, Devereux, Michael P., van der Horst, Albert, Loretz, Simon and Ruud A. de Mooij, Corporate tax harmonization in the EU

WP09/31 Karkinsky, Tom and Nadine Riedel, Corporate Taxation and the Choice of Patent Location within Multinational Firms

WP09/30 Becker, Johannes and Clemens Fuest, Transfer Pricing Policy and the Intensity of Tax Rate Competition

WP09/29 de la Feria, Rita, VAT and the EC Internal Market: The Shortcomings of Harmonisation

WP09/28 Damjanovic, Tatiana and David Ulph, Tax Progressivity, Income Distribution and Tax Non-Compliance

WP09/27 Grubert, Harry, MNC Dividends, Tax Holidays and the Burden of the Repatriation Tax: Recent Evidence

WP09/26 Grubert, Harry, Foreign Taxes, Domestic Income, and the Jump in the Share of Multinational Company Income Abroad

WP09/25 Maffini, Giorgia, Tax Haven Activities and the Tax Liabilities of Multinational Groups

WP09/24 Bach,Laurent and Nicolas Serrano-Velarde, The Power of Dynastic Commitment 